\title{
Ders İmecesi Modeli ve Modelin Öğretmen Mesleki Gelișimine Katkısı Üzerine Bir İnceleme ${ }^{1}$
}

\begin{tabular}{ccc}
\hline MAKALE TÜRÜ & Başvuru Tarihi & Kabul Tar \\
Derleme Makalesi & 24.10 .2018 & 31.05 .2019 \\
\hline İlknur Bayram iD & 2 \\
TED Üniversitesi \\
Fatma Bıkmaz iD ${ }^{3}$ \\
Ankara Üniversitesi
\end{tabular}

\section{Öz}

$\mathrm{Bu}$ araştırmada etkili bir mesleki gelişim uygulamasının örneklerinden olan Ders İmecesi Modeli ve modelin öğretmenlerin mesleki gelişimine katkıları incelenmiştir. Araştırmada, alanyazında yenilikçi mesleki gelişim modellerine örnek olarak gösterilen Ders İmecesi Modelinin nasıl uygulandığının ayrıntılı olarak incelenmesi hedeflenmiştir. Dünyada ve Türkiye'de gerçekleștirilen araștırmalar 1șı̆ı̆ında modelin öğretmenlerin mesleki gelișimine, öğretmenler arası işbirliği, öğrenciye ve öğrenme sürecine odaklanma, alan ve öğretmenlik alan bilgisi ve yansıtıcı düşünme becerileri noktalarında katkı sağladığı sonucuna ulaşılmıştır. Modelin hem hizmet öncesi hem de hizmet içi öğretmen eğitiminde ve farklı kademelerde görev yapan öğretmen gruplarıyla uygulanması önerilmektedir. Böylelikle modelin Türkiye'de yaygınlaştırılması, iyi giden yönlerinin saptanması ve aksayan yönlerinin düzeltilmesi konusunda ortak bir akıl oluşması sağlanabilir.

Anahtar sözcükler: Ders imecesi, öğretmen mesleki gelişimi, yenilikçi mesleki gelişim modeli.

${ }^{1} \mathrm{Bu}$ makale, İlknur Bayram'ın Prof. Dr. Fatma Bıkmaz danışmanlığında hazırladığı "Ders imecesi: İngilizce hazırlık programı ögretmenlerinin liderliğinde bir mesleki gelişim uygulaması" isimli Doktora Tezinden üretilmiștir.

${ }^{2}$ Sorumlu Yazar: Dr, Öğretme-Öğrenme Merkezi, Eğitim Programlanı ve Öğretim Uzmanı, E-posta: ilknur.bayram@tedu.edu.tr, https://orcid.org/0000-0001-8109-8051

${ }^{3}$ Prof. Dr., Eğitim Bilimleri Fakültesi, Eğitim Bilimleri Bölümü, Eğitim Programları Anabilim Dalı, Eposta: b1kmaz@ankara.edu.tr, https://orcid.org/0000-0002-7156-1425 
Günümüzde bilgiye ulaşmak giderek daha da kolaylaşmakta ve bilgi hızla paylaşılmaktadır. $\mathrm{Bu}$ durum öğretmenlik mesleğinde köklü değişikliklere neden olmakta, öğretmeni bilginin kaynăg 1 olarak gören anlayış yerini bilgiye ulaşmada öğrencilere kılavuzluk eden öğretmen niteliklerine önem veren anlayışa bırakmaktadır (Milli Eğitim Bakanlığı, 2017). Çağın gereklilikleri çerçevesinde değişim gösteren öğretmenlik rollerine uyum sağlanabilmesi ancak sürekli hizmet içi mesleki gelişim ile olanaklıdır. Ancak, Avrupa Ekonomik İşbirliği Örgütünün 2008 yılında Türkiye'nin de katıldığı Uluslararası Öğretme ve Öğrenme Araştırmasının sonuçlarına dayalı olarak hazırladığı rapor (Uluslararası Öğretme ve Öğrenme Araştırması, 2009), aralarında Türkiye'nin de bulunduğu bazı ülkelerde, her dört öğretmenden birinin mesleki gelişim etkinliklerine katılmadığını, katılan öğretmenlerin ise mesleki gereksinimlerini karşılama konusunda bu etkinlikleri yetersiz bulduğunu ortaya koymuştur. Raporda ayrıca öğretmenlerin kendi ilgi ve gereksinimlerine uygun mesleki gelişim olanaklarından yoksun olduğu da belirtilmektedir. Bu durum öğretmenlerin mesleki gelişimlerine yönelik çalışmalara katılmaları konusunda desteklenmesi gerektiğini göstermektedir. Raporda, öğretmenlerin katıldıkları mesleki gelişim etkinliklerinin gereksinimlerine yönelik olup olmadığının değerlendirilmesi gerektiği de gözler önüne serilmektedir.

Hizmet içi mesleki gelişimin niteliğinin öğretimin niteliğini, öğretimin niteliğinin de öğrenci başarısını etkilediği bilinmektedir (Darling-Hammond, 1997; Sparks, 2002). Bu noktadan hareketle, öğretmenlerin mesleki gelişiminin eğitimin niteliğini belirlediği ve yaşama geçirilmek istenilen eğitim reformlarında kilit rol oynadığ 1 görülmektedir (Bümen, Ateş, Çakar, Ural ve Acar, 2012). Öğretmenlerin mesleki gelişimi, ülkelerin öncelik verdiği konuların başında gelmektedir. Mesleğe yeni başlayan öğretmenlerin mesleğe uyum sağlamaları mesleki gelişimle olanaklıdır (Fraser, Kennedy, Reid ve Mckinney, 2007). Mesleki gelişim sayesinde öğretmenlik uygulamalarında ve öğrencilerin öğrenmesinde ilerleme kat edildiği (Borko, 2004) ve okul başarısının arttığı da bilinmektedir (Bolam, 2000). Bu nedenle mesleki gelişimin niteliği sürekli sorgulanması gereken bir konudur (Mokhele, 2013).

Öğretmenlerin mesleki gelişimi için geleneksel veya yenilikçi birçok farklı model sunulmaktadır. İçerik ve biçim olarak farklılık gösteren bu modeller ortak bir amaca hizmet etmektedir. Bu amaç, öğretmenlerin sınıf içi uygulamalarını, tutum ve inançlarını olumlu yönde değiştirmek ve bu sayede öğrencilerin akademik başarılarını artırmaktır (Guskey, 2002). Ancak, hizmet içi eğitimi tek seferlik ders veya seminerlerle öğretmenlere bilgi ve beceri kazandırılması süreci olarak gören geleneksel anlayış; okul bağlamından uzak olması, sınıf içi uygulamalarla iç içe olmaması ve güncel öğretme ve öğrenme kuramlarını dikkate almaması nedeniyle eleştirilerle karşı karşıya kalmaktadır (Borko, Jacobs ve Koellner, 2010). Öğretmenlerin nasıl öğrendiğini dikkate almayan, yüzeysel bilgilerle dolu ve bir bütüne hizmet etmeyen, bölük pörçük parçalar şeklinde sunulan hizmet içi eğitim seminerlerinin maliyeti de yüksektir (Ball ve Cohen, 1999; Bill and Melinda Gates Foundation, 2015). Bu tür mesleki gelişim etkinliklerinin öğretmenlerin sınıf içi uygulamalarına yansıması ve dolayısıyla da mesleki gelişimlerini olumlu etkilemesi 
zor görünmektedir. Joyce ve Showers (2002) öğretmenlere sunulan hizmet içi eğitimin sınıf uygulamalarına yansımasını incelemiş ve yalnızca sunum, anlatım ve gösterim şeklinde yürütülen eğitimlerin sınıfa yansımadığını belirtmiştir. Bu eğitimler uygulama ile birleştiğinde sınıfa yansıması \% 5'e, rehberlik, danışmanlık, yönetim desteği ve geri bildirim ile birleştiğinde ise \% 95'e çıkmaktadır. Bu nedenle McDonough ve McDonough (1997) öğretmenlere sunulan mesleki gelişim modellerinde değişikliğe gidilmesi gerektiğini belirtmekte ve öğretmenlerin mesleki gelişime etkin ve sürekli katılımlarına olanak sağlayan ve sınıf içi kararlarda kendilerine söz hakkı tanıyan modellerin benimsenmesi gerektiğinin altını çizmektedir. Geleneksel mesleki gelişim uygulamalarının yetişkin öğrenme ilkelerini göz ardı ettiğinin (Richards ve Farrell, 2005) ve bu yöntemlerin öğretmenlerin değişen mesleki gelişim gereksinimlerini karşılamada yetersiz kaldığının (Little, 2006) altını çizen araştırmacılar da geleneksel mesleki gelişimin yerini daha etkili bir mesleki gelişim anlayışına bırakması gerektiğini belirtmektedir. Öğrenme ve öğretim ile ilgili araştırmalar 1şı̆̆ında davranışçı yaklaşım yerini yapılandırmacı yaklaşıma bırakmış, bunun doğal bir sonucu olarak mesleki gelişime bakış açısı da değişikliğe uğramıştır. Geleneksel mesleki gelişim modellerinden duyulan memnuniyetsizlik etkili bir mesleki gelişim modelinin nasıl olması gerektiği sorusunu da beraberinde getirmiştir.

Nitelikli ve etkili mesleki gelişim programlarının öğretmenlik meslek bilgisini artırdığı, öğretmenlik uygulamalarını geliştirdiği (Borko, 2004) ve öğretimin niteliğini artırdığ (Brown Easton, 2011) söylenebilir. Etkili mesleki gelişim süreklilik gösteren, içerisinde eğitim, uygulama ve geri bildirim olan, öğretmenlere gereksinim duydukları rehberlik ve desteği sağlayan bir yapıda olmalıdır (Avrupa Ekonomik İşbirliği Örgütü, 2005). Bir mesleki gelişim programının etkili olabilmesi için hem öğrenci hem de öğretmen ilgi ve gereksinimlerini dikkate alması, öğrencilerin öğrenmesine odaklanması, öğrenci merkezli öğretimi desteklemesi, zamana yayılması ve süreklilik göstermesi gerektiği bilinmektedir (Edmond ve Burns, 2005). Yenilikçi bakış açısı mesleki gelişimi, öğretmen merkezli, uzun süreli ve meslekle bütünleşik öğrenme deneyimleri olarak görmektedir (Bümen ve diğ., 2012). Mesleki gelişimin etkili olabilmesi için öğrencilerin öğrenme çıktılarına olumlu yansıması ve öğretmenlik uygulamalarında değişiklik yaratarak öğretimi iyileştirmesi gerektiği de bilinmektedir (Bubb ve Early, 2007).

Riding (2001) etkili mesleki gelişimin, süreklilik gösteren, yansıtıcı düşünme ve araştırma olanağı sunan, akranlarla iletişim içinde yürütülen, okul temelli, işbirliğine dayalı, ulaşılabilir ve kapsamlı olması gerektiğini belirtmiştir. Zepada (2012) etkili mesleki gelişimin merkezinde mesleki öğrenmenin yattığını belirtmekte, mesleki öğrenmenin ise kişinin kendi uygulamalarından, meslektaşlarından ve öğrencilerinden öğrendikleri çerçevesinde şekillendiğini belirtmektedir. Etkili mesleki gelişimin öğelerinden bir diğeri de etkin öğrenmedir. Öğretmenlere gözlem yapma, ders planlama, öğrenci ürünlerini gözden geçirme, bir tartışmayı yürütme, sunum yapma ve rapor yazma gibi olanaklar sunan uygulamaların daha etkili uygulamalar olduğu bilinmektedir (Birman, Desimone, Porter ve Garet, 2000). Coolahan (2002) hizmet içi mesleki gelişim etkinliklerinin etkili olabilmesi için, okul 
içi ve okul dışı etkinlikleri kapsaması, öğretmenlerin içeriği belirlemede söz sahibi olması, programa etkin bir şekilde katılması ve meslektaşları ile işbirliği ve etkileşim içerisinde çalışması gerektiğini belirtmiş̧tir. Alanyazında belirtilen etkili mesleki gelişim etkinliklerinin birçok özelliğini yapısında bulunduran modellerden birisi Ders İmecesi Modelidir.

Bu çalışma, Ders İmecesi Modelini tanıtmayı ve modelin öğretmenlerin mesleki gelişimlerine katkılarını dünyada ve Türkiye'de gerçekleştirilen araştırmalar ışığında ele almayı amaçlamaktadır. Ders İmecesi ile ilgili İngilizce alanyazında oldukça fazla çalışma bulunmaktadır. Ancak modelin nasıl uygulanacağını ayrıntılı bir şekilde ve farklı araştırmacıların bakış açısıyla ele alan Türkçe çalışmaların sayısı azdır. Bu çalışma bu alandaki eksikliği gidermek amacıyla gerçekleştirilmiştir.

\section{Ders İmecesi Modeli}

Ders İmecesi Japonya'da 1870'li y1lardan beri uygulanmakta olan (Dudley, 2014) işbirliğine dayalı bir mesleki gelişim modelidir (Fernandez ve Yoshida, 2004; Lewis ve Tsuchida, 1998; Murata, 2011; Stigler ve Hiebert, 1999). Ders İmecesi Japonya'da öğretimin niteliğini artırmak ve öğrencilerin daha zengin öğrenme deneyimleri yaşamalarını sağlamak amacıyla uygulanmaktadır (Fernandez ve Yoshida, 2004). Bu modelde öğretmenler işbirliği içerisinde bir ders planı hazırlar, hazırlanan ders planını uygular, gözlem yapar ve gözlemleri sonucunda topladıkları veriler ışığında ders planlarında gerekli gördükleri düzeltmeleri yaparlar (Stepanek, Appel, Leong, Turner Mangan ve Mitchell, 2007).

Japoncada ders anlamına gelen jugyo ve bilimsel araştırma ya da bilimsel çalışma anlamına gelen kenkyu kelimelerinin bir araya gelmesinden oluşan jugyokenkyu kavramı İngilizceye Lesson Study ya da Lesson Research olarak çevrilmiş̧ir (Fernandez ve Yoshida, 2004; Lewis, 2000; Yoshida, 1999). İngilizce Lesson Study kavramı yerine ise Türkçede Ders Çalı̧̧ması (Bayram, 2010), Ders Araștırması (Eraslan, 2008; Erbilgin, 2013; Günay, Yücel Toy ve Bahadır, 2016; İ. Budak, A. Budak, Bozkurt ve Kaygın, 2011; Kıncal ve Beypınar; 2015; Özaltun, 2014) ve Ders Ímecesi (Baki, 2012; Baki, Erkan ve Demir, 2012; Boran ve Tarım, 2016; Bütün, 2015; Cumhur ve Güven, 2015; Kanbolat, 2015; Serbest, 2014; Yıldız, 2013) kavramları kullanılmaktadır. Ders İmecesi Modelinde öğretmenler tarafindan birlikte planlanan, uygulanıp gözlemlenen ders ya da derslere Japoncada jugyokenkyu kavramındaki kelimelerin yer değiştirmesiyle oluşan kenkyujugyo, İngilizcede ise Lesson Study kavramındaki kelimelerin yer değiştirmesiyle elde edilen study lesson ya da research lesson adı verilmektedir (Cerbin, 2011; Fernandez ve Yoshida, 2004; Lewis ve Hurd, 2011; Stigler ve Hiebert, 1999). Söz konusu kavramın Türkçe karşıllı̆ının ise araştırma dersi olduğu görülmektedir (Baki, 2012; Kıncal ve Beypınar, 2015; Özaltun, 2014).

Ders İmecesi Modeli batıda içinde bulunulan yüzyılda popüler olmuştur (Dudley, 2014). Batılı eğitimcilerin Ders İmecesinin farkına varmaları 1990'lı yılların sonuna denk gelmektedir (Cerbin, 2011). Stigler ve Hiebert tarafindan 1999 yllında 
yazılan The Teaching Gap: Best Ideas from the World's Teachers for Improving Education in the Classroom isimli kitap, Amerika'nın Ders İmecesi ile tanışmasını sağlamış ve Amerika'da 2000'li yılların başından itibaren Ders İmecesi uygulamaları yapılmaya başlanmıştır. 2002 yılında International Comission on Mathematical Instruction tarafindan düzenlenen konferansın ana konularından birisi olan Ders İmecesi bu tarihten sonra birçok ülkeye yayılmıştır (Murata, 2011). Model bugün Singapur, Hong Kong ve Çin gibi Doğu Asya ülkeleri ile batıda Amerika, İngiltere, İsveç ve Kanada gibi ülkelerde uygulanmaktadır (Dudley, 2014).

Japonya'da mesleki gelişim yoluyla sınıf içi uygulamaların geliştirilmesi öğretmenlerin öncelikli sorumlulukları arasında yer almaktadır. Öğretmenlik mesleğine başlayan her öğretmen kounaikenshuu adı verilen okul temelli sürekli mesleki gelişim sürecinin bir parçası olmaktadır. Japonya'da bulunan her ilk ve ortaokulda kounaikenshuu yer almaktadır. Öğretmen liderliğinde yürütülen kounaikenshuu farklı etkinlikleri yapısında barındıran kapsamlı ve okul temelli bir mesleki gelişim sürecidir. Kounaikenshuu'nun en yaygın bileşenlerinden birisi de Ders İmecesi uygulamasıdır (Fernandez ve Yoshida, 2004; Stigler ve Hiebert, 1999; Yoshida, 1999). Japonya'da Ders İmecesi ilkokul ve liselerde görev yapan öğretmenlerin neredeyse tamamı tarafından yılda en az bir kez yapılmaktadır (WangIverson ve Yoshida, 2005).

Diğer ülkelerde özellikle matematik alanında ve okul temelli gerçekleştirilen Ders İmecesi uygulaması Japonya'da küçük, orta ve büyük ölçekli olmak üzere farklı ölçeklerde yapılmaktadır (Murata, 2011). Japonya'da Ders İmecesi küçük ölçekte tek bir okul düzeyinde, orta ölçekte ise aynı bölgede yer alan birden fazla okulun bir araya gelmesiyle yapılır. Ulusal düzeyde gerçekleştirilen büyük ölçekli uygulamalar da vardır. Ancak bu uygulamalardan en yaygın olanı aynı okulda görev yapan öğretmenler tarafından okul düzeyinde gerçekleştirilen Ders İmecesi uygulamalarıdır (Baba, 2007). Japon öğretmenler kariyerleri boyunca farklı ölçeklerde gerçekleştirilen bir çok Ders İmecesi uygulamasında yer alma olanağına sahiptir.

Lewis ve Hurd (2011) öğretimin niteliğini artırmak isteyen öğretmenlerin bir araya gelerek derslerini planlamalarının ve bu planların öğrenciler üzerindeki etkilerini araştırmalarının kolaylıkla uygulanabilir göründüğ̈nü, bu nedenle de Ders İmecesinin ilk bakışta kolay görünen bir uygulama olduğunu belirtmektedir. Ancak başlangıçta basit gibi algılanabilecek Ders İmecesi Modelinin hedef belirlenmesi, veri toplanması, çözümlenmesi ve sonuçların raporlaştırılması gibi karmaşık süreçler içerdiğine dikkat edilmesi gerektiğinin de altı çizilmektedir (Lewis ve Hurd, 2011).

Cerbin (2011) de Ders İmecesi uygulamak için yüksek lisans veya doktora dereceleri gibi ileri düzeyde eğitim görülmesi gerekmediğini, daha önce Ders İmecesi uygulaması yapmış deneyimli öğretmenler eşliğinde uygulama yapılabileceğini belirtmektedir. Ancak modelin rastgele uygulanan, hafife alınabilecek bir yapısı olmadığının, aksine sistematik araştırma gerektiren oldukça iyi yapılandırılmış uygulama ve süreçleri içeren aşamalardan oluştuğunun da altı çizilmektedir. 


\section{Ders İmecesi Modelinin Așamaları}

Ders İmecesi Modelinin tam anlamıyla anlaşılması uygulama sırasında izlenecek adımların yeterince anlaşılmasına bağlidır (Stepanek ve diğ., 2007). Bu süreçte birlikte çalışacak olan öğretmenlerin izlemeleri gereken aşamalar araştırmacılar tarafından farklı şekillerde sıralanmaktadır. Tablo 1'de farklı araştırmacılar tarafından Ders İmecesi sürecinde yer alması gerektiği belirtilen aşamalar sunulmaktadır.

Tablo 1'den de anlaşılabileceği gibi her ne kadar araştırmacılar tarafından belirtilen aşama sayısı farklı olsa da Ders İmecesi sürecinde birbirini izlemesi gereken dört temel aşama vardır. Bu aşamalardan ilki araştırma dersinin planlanması aşamasıdır. Planlama aşamasını sırasıyla araştırma dersinin uygulanması, değerlendirilmesi ve son olarak da sonuçların paylaşılması aşamaları izlemektedir. $\mathrm{Bu}$ aşamalar aşağıda ayrıntılı bir şekilde ele alınmıştır.

1. Aşama: Araştırma dersinin planlanması. Bu aşamada yapılacak olan en önemli iş birinci araştırma dersinin hazırlanmasıdır (Yoshida, 1999). Birinci araştırma dersi hazırlanmadan önce Ders İmecesi grubunda birlikte çalışacak öğretmenlerin bir araya gelerek bir Ders İmecesi grubu oluşturmaları gerekmektedir. Ders İmecesi grubu oluşturulurken öğretmenlerin dikkat etmesi gerekenler aşağıdaki şekilde özetlenebilir.

- Grupta yer alacak olan öğretmenler birbirleriyle iyi anlaşabilen kişiler olmalıdır (Lewis ve Hurd, 2011).

- Grup üyelerinden en az birinin deneyimli öğretmenler arasından seçilmesi ve üyelerin farklı öğretmenlik deneyimlerine sahip olması gerekmektedir (Dudley, 2014).

- Lewis ve Hurd'e göre (2011) Ders İmecesi grubunda birlikte çalş̧acak öğretmenlerin sayısı dört ile altı, Cerbine'e göre (2011) ise üç ile altı arasında olmalıdır. Dudley (2014) ise bu sayının üçü geçmemesi gerektiğini belirtmektedir.

- Grup üyeleri kendileri için yeni bir mesleki gelişim uygulaması olan Ders İmecesini denemeye gönüllü olmalıdır (Dudley, 2014).

- Grup üyeleri Ders İmecesi uygulamasının ne olduğu, nasıl yapıldığı ve kendi mesleki gelişimlerine ne gibi katkılar sağlayacağı ile ilgili ortak bir görüşe sahip olmalıdır (Lewis ve Hurd, 2011).

- Grup üyeleri planladıkları derslere onun ya da benim dersim gözüyle değil bizim dersimiz gözüyle bakmalıdır (Lewis ve Hurd, 2011). 


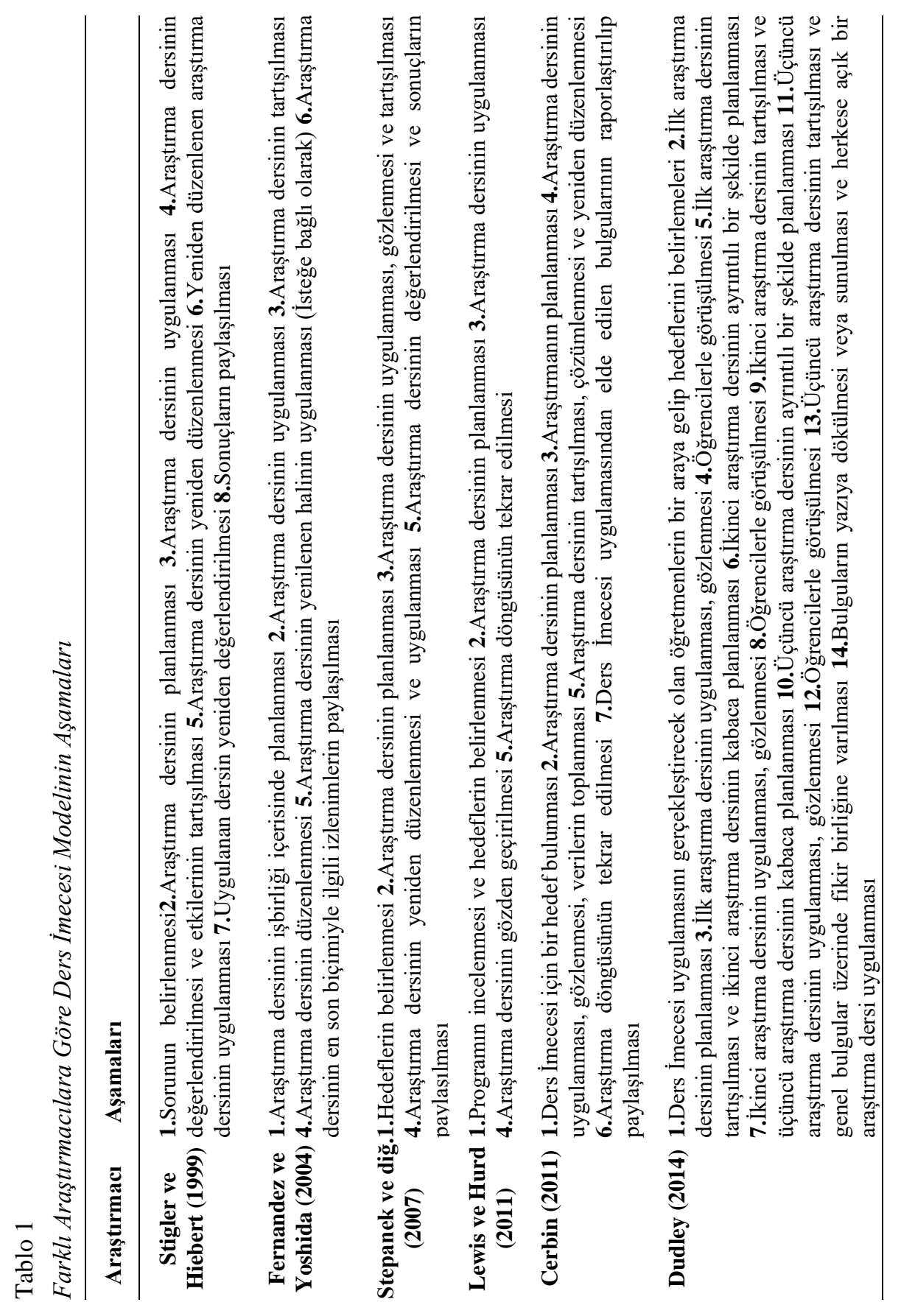


- Grup üyeleri Ders İmecesi ile ders gözlemi uygulamalarını birbirine karıştırmamalıdırlar. Ders gözlemlerinde gözlenen şey öğretmenin kendisi ve onun sınıf içinde yaptıklarıyken, Ders İmecesinde gözlem öğrencilerin öğrenme ve düşünce süreçlerine odaklanmaktadır (Lewis ve Hurd, 2011).

- Grup üyeleri Ders İmecesi sürecinde kendilerinden neler beklendiği ve grup içindeki rolleri konusunda uzlaşmaya varmalıdır (Dudley, 2014). Bir grup üyesi süreç boyunca planı uygulayan, grubu yöneten, not alan, toplantı kayıtlarını tutan, toplantı süresini kontrol eden, toplantıları düzenleyen, araştırma yapan, özet çıkaran kişi olmak üzere birçok farklı rol üstlenebilir (Cerbin, 2011; Lewis ve Hurd, 2011).

- Grup üyeleri Ders İmecesi süreci boyunca uyacakları kurallar listesi oluşturmalıdır (Dudley, 2014; Lewis ve Hurd, 2011). Üyeler bir akademik yıl boyunca bir arada çalışacakları için son teslim zamanlarına uyma, toplantılara zamanında katılma, işleri eş güdümlü bir şekilde yürütme gibi konularda bir arada kararlar almalı ve bu kararlar doğrultusunda hareket etmelidirler (Cerbin, 2011).

- Grup üyeleri Ders İmecesi döngüsünde yapmaları gerekenler için bir çalışma planı hazırlamalıdır (Cerbin, 2011; Lewis ve Hurd, 2011).

Ders İmecesi grubunda birlikte çalışacak öğretmenler bir araya gelerek çalışmak istedikleri ünite ve konuyu belirler. Ünite ve konunun belirlenmesinin ardından öğretmenler hem ders kitaplarına hem de öğretmen kılavuz kitaplarına başvurarak araştırma dersinin hedeflerini belirler (Yoshida, 1999). Hedeflerin belirlenmesi sürecinde öğrenci gelişimi açısından uzak hedeflerin de göz önünde bulundurulması, programın ve ulaşılması gereken standartların da incelenmesi gerekmektedir (Lewis ve Hurd, 2011). Dersin hedefleri belirlendikten sonra hedeflerin nasıl gerçekleştirileceği ve dersin nasıl işleneceği üzerinde çalışılır. Bu aşamada planlanan araştırma dersinin diğer derslerle olan bağlantısı ve bu dersin okulun eğitim ve öğretim programı içerisindeki yeri göz önünde bulundurulur. Araştırma dersinde kullanılacak olan materyallere de karar verildikten sonra taslak niteliğinde yazılı bir ders planı hazırlanır (Yoshida, 1999). Bu planda programın uzak hedefleri, öngörülen öğrenci düşünme süreçleri, veri toplama planı, benimsenen öğretim yöntemleri ve seçilen yöntem için gerekçeler yer almalıdır (Lewis ve Hurd, 2011). Söz konusu taslak plan bütün öğretmenlerin yer aldığı öğretmenler toplantısında sunulur ve ders planlama aşamasında yer almayan öğretmenlerin planla ilgili görüşleri de alındıktan sonra planda gerekli görülen değişiklikler yapılır. Araştırma dersini gözleme gelecek öğretmenlerin tamamına ders planının son şeklinin dağıtılmasıyla bu aşama sona erer (Yoshida, 1999). Araştırma dersi için plan yapılırken asıl amacın mükemmel bir ders planlamak değil bir öğretim yöntemi ya da öğrenme ile ilgili merak edilen bir konunun ders ortamında çözümlenmesi olduğu unutulmamalıdır (Murata, 2011).

2. Aşama: Araştırma dersinin uygulanması. Ders planının hazırlanmasının hemen ardından araştırma dersi sınıfta uygulanır. Araştırma dersinin uygulanması, 
hazırlanan ders planının sınıf ortamında denenmesine olanak tanımasının yanı sıra gözlem ve değerlendirme için temel oluşturması bakımından Ders İmecesinin en önemli aşamalarından birisidir (Doig ve Groves, 2011).

$\mathrm{Bu}$ aşamada birinci araştırma dersinin planlanması sürecinde yer alan öğretmenlerden birisi hazırlanan ders planını kendi sınıfında uygular. Araştırma dersinde doğal sınıf atmosferinin bozulmaması ve öğrencilerin gerçek davranışlarını yansıtmaları önemli olduğu için derslerin öğretmenlerin her zamanki sınıflarından birinde ve hatta kendi dersliklerinde yapılması önerilmektedir (Takahashi ve Yoshida, 2004).

Araştırma dersi sırasında Ders İmecesi grubunda yer alan diğer öğretmenler ve bazen de okuldaki öğretmenlerin tamamı araştırma dersini gözlemler (Lewis, 2002a). Öğretim üyeleri, Milli Eğitim Bakanlığı'ndan gelen uzmanlar ve konu alanı uzmanları da gözlemci olarak sinıfta bulunabilir (Baba, 2007). Gözlemciler uygulama sonrasında yapılacak olan toplantılarda dersi anlatan öğretmene geri bildirimde bulunabilmek için gözlem süresince not tutar. Araştırma dersini gözlemleyen öğretmenlerin tamamı ders planını önceden okumuş oldukları için ders ile ilgili fikir sahibidir. Dolayısıyla gözlem süresince dersin işlenişinden çok öğrencilerin anlama süreçlerine ve derste karşılaştıkları problemleri nasıl çözdüklerine odaklanılmaktadır (Cerbin ve Kopp, 2006). Gözlemciler araştırma dersinde dersi anlatan öğretmeni eleştirmek için bulunmadıklarının bilincinde olmalıdır (Stigler ve Hiebert, 1999). Araştırma dersinde gözlemin amacı dersin etkililiği ile ilgili olabildiğince ayrıntılı veri toplamaktır (Stepanek ve diğ., 2007). Ayrıca gözlemcilerin ders sirasında ögrencilerle konuşmamaları, onlara öneride bulunmamaları ve yanıtlarıyla ilgili yorum yapmamaları da gerekmektedir (Takahashi ve Yoshida, 2004).

Lewis ve Tsuchida (1998) araştırma derslerini normal derslerden ayıran özellikleri aşağıdaki şekilde sıralamıştır. Araştırma dersleri;

- diğer öğretmenler tarafından gözlemlenir,

- birden fazla öğretmen tarafından dikkatli bir şekilde planlanır,

- belli bir hedef ya da eğitim felsefesi üzerine odaklanılarak tasarlanır,

- video veya ses kayıt cihazları ve gözlem notları yoluyla kayıt altına alınır,

- dersi gözlemleyen öğretmenlerin ve / veya dış uzmanların katılımıyla çözümlenir ve gözden geçirilir.

3. Aşama: Araştırma dersinin değerlendirilmesi. Birinci araştırma dersinin uygulanmasının ardından dersle ilgili izlenimlerin paylaşılması için toplantılar yapılır. Bu toplantılardan ilki dersin uygulandığı gün yapılmaktadır (Lewis ve Hurd, 2011). İlk toplantının uygulama ile aynı gün yapılması alınan notlar ve izlenimler unutulmadan paylaşılması açısından önemlidir. Toplantı, dersi işleyen öğretmenin dersle ilgili izlenimlerini grubun geri kalanı ile paylaşmasıyla başlar. Sonrasında gözlem yapan öğretmenlerin görüş ve düşünceleri dinlenir. Toplantıda paylaşılan 
fikirlerin tamamı dersi işleyen öğretmen tarafından not edilir (Fernandez ve Yoshida, 2004).

İlk toplantı sonrasında grupta yer alan öğretmenler bir ya da birkaç kez daha bir araya gelerek ders planlarında gerekli gördükleri değişiklikleri yapar ve ikinci araştırma dersini planlamaya başlar (Cerbin, 2011). Bazı durumlarda grupta yer almayan öğretmenlerin de katılımıyla toplantılar yapılarak ders planında düzenlemeye gidildiği de görülmektedir (Murata, 2011). Düzenlemeler araştırma dersi sırasında toplanan veriler temel alınarak yapılır ve yeniden düzenlenen ders planı için gerekli görülen materyaller hazırlandıktan sonra ikinci araştırma dersinin ders planı uygulamaya hazır duruma getirilir (Stepanek ve diğ., 2007).

Gerekli iyileştirilmeler yapılan ikinci araştırma dersi de aynen ilk araştırma dersinde olduğu gibi grupta yer alan bir öğretmen tarafından uygulanır, gözlem sonrası değerlendirme toplantıları yapılarak düzenlenir. Gerekli görülmesi durumunda üçüncü araştırma dersi için ders planı hazırlanması, hazırlanan bu ders planının uygulanması, dersin gözlenmesi ve değerlendirilmesi ile süreç son bulur (Dudley, 2014). Bazı Ders İmecesi grupları birinci araştırma dersinden sonra süreci sonlandırmay1, ikinci ve üçüncü araştırma derslerini uygulamamayı tercih etmektedir. Eğer süreç sonlandırılmayacaksa araştırma derslerini uygulayacak öğretmen ve derslerin uygulanacağı sınıfların değiştirilmesi önerilmektedir (Fernandez ve Yoshida, 2004).

Cerbin (2011) araştırma derslerinin çözümlenmesi için yapılan toplantılarda üç ana soruya odaklanılması gerektiğine değinmektedir;

1. Öğrenciler dersin hedeflerine hangi yollarla ulaştı? Ders öğrencilerin öğrenme düzeyini, katılımını ve düşünmesini nasıl destekledi?

2. Toplanan veriler ışı̆̆ında derste ne gibi düzenlemeler yapılması gerekmektedir?

3. Grup üyeleri dersten öğretme ve öğrenme süreçleri ile ilgili neler öğrendiler?

Değerlendirme toplantılarında bu sorulara verilecek yanıtlar ışığında araştırma dersi değerlendirilir ve gerekli görülen düzenlemeler yapılır.

4. Aşama: Ders imecesinin sonuçlarının paylaşılması. Araştırma dersleri bittikten sonra Ders İmecesi uygulamasından elde edilen sonuçların paylaşılması gerekmektedir. Japonya'da Ders İmecesinin sonuçlarını paylaşmak için Ders İmecesinin yapıldı ğı okuldaki öğretmen ve davetlilerden oluşan büyük bir grup gözlemcinin katılımıyla araştırma dersi son bir kez uygulanır (Baba, 2007). İsteyen herkesin katılımına açık olan bu araştırma dersinin amac1;

- Ders İmecesi sonuçlarının diğer okullara paylaşılmasının sağlanması,

- araştırma dersi ile ilgili davetlilerin de katılımıyla tartışmalar yapılması, 
- ders planlarının ve okulun Ders İmecesi sürecinde gösterdiği başarıların ve karşılaştı̆̆ı zorlukların yer aldığı bir kitapçığın davetlilerle paylaşılması,

- araştırmacı ve diğer konu alanı uzmanlarının araştırma dersi ile ilgili görüşlerinin alınmasıdır (Yoshida, 1999).

Herkese açık bir şekilde gerçekleştirilen araştırma derslerinden sonra Ders İmecesi raporunun yazılması ile süreç son bulur. Japonya'da öğretmenler Ders İmecesi raporlarını yayınlamakta ve yayınlanan raporların sayıs1 üniversitedeki araştırmacıların yaptıkları yayın sayısını geçmektedir (Takahashi ve Yoshida, 2004). Amerika ve İngiltere'de ise sürecin sonuçları genellikle öğretmenler tarafindan hazırlanan sunum ve raporlar yoluyla okuldaki diğer öğretmenlerle paylaşılmaktadır (Cerbin, 2011; Dudley, 2014). Ders İmecesi raporu da sürecin diğer aşamalarında olduğu gibi grupta yer alan tüm öğretmenlerin katılımıyla yazılmaktadır. Raporda;

- Ders İmecesi için belirlenen hedefler ve bu hedeflerin belirlenme nedenleri,

- Ders İmecesi süreci ile ilgili öğretmen görüş ve düşünceleri,

- Ders İmecesi sürecinin iyi giden yönleri ve zorlukları,

- Ders İmecesi süresince yapılanlar

yer almaktadır (Takahashi ve Yoshida, 2004). Raporun ekinde Ders İmecesi süresince birinci ve varsa ikinci ve üçüncü araştırma dersi için hazırlanan ders planları ve yapılan değerlendirme toplantılarında tutulan notlara da yer verilebilir (Cerbin ve Kopp, 2006).

Temel olarak yukarıda sıralanan dört aşamadan oluşan Ders İmecesi çalışmasına dış uzmanlar da katılabilir. Dış uzmanlar, alan bilgisi, alan öğretim bilgisi, Ders İmecesi uygulaması ve gereksinim duyulan diğer alanlarda bilgi, deneyim ve görüşüne başvurulan kişilerdir (Stepanek ve diğ., 2007). Watanabe (2002) dış uzmanların Ders İmecesindeki rolünü aşağıdaki şekilde özetlemiştir. Dış uzmanlar;

- Ders İmecesi sürecinin yönetilmesi,

- toplantıların daha etkili bir şekilde yürütülmesi,

- gerek duyulduğunda öğretmenlere konu alanı ile ilgili danışmanlık sağlanması

vb. noktalarda sorumluluk alabilirler. Dış uzmanlar Ders İmecesi sürecinin başından sonuna kadar grupla birlikte çalışmak zorunda değildir. Gerek görüldüğü zamanlarda toplantılara ya da araştırma derslerine çağrllabilirler (Fernandez ve Yoshida, 2004).

Yukarıda aşamaları açıklanan Ders İmecesi Japon eğitim sisteminin önemli bir öğesidir. Model, Japonya'daki ilkokullarda görev yapan öğretmenlere sınıf içi uygulamalarını geliştirme olanağı sunmuş (Lewis ve Tsuchida 1998) ve Japonya'da matematik eğitiminde öğretmen merkezli eğitimden öğrenci merkezli eğitime geçilmesinde öncü olmuştur (Yoshida, 1999). 


\section{Ders İmecesi Modelinin Öğretmenlerin Mesleki Gelișimine Katkıları}

Dünyada ve Türkiye'de Ders İmecesi Modeli ile ilgili araştırmalar incelendiğinde modelin, öğretmenlerin mesleki gelişimine öğretmen işbirliği, yansitıcı düşünme becerileri, öğrenciye ve öğrenme sürecine odaklanma, araştırma becerileri, alan ve öğretmenlik alan bilgisi, öğretmen motivasyonu alanlarında katkı sağladığı ortaya çıkmıştır.

Öğretmen işbirliği. Ders İmecesi Modelinin yaşama geçirilmesi öğretmenlerin işbirliği ve dayanışma içerisinde çalışmalarına bağlıdır. Araştırmalar modelin öne çıkan en önemli özelliklerinden birisinin öğretmen işbirliğini desteklemesi ve artırması olduğunu ortaya çıkarmıştır.

Öğretmenler dersleri birlikte planlayarak, gözlemleyerek ve çözümleyerek takım olarak çalıştıklarını ve bu sayede öğretmenlik becerilerini geliştirdiklerini belirtmektedir (Lewis ve Tschudia, 1998). Ders İmecesinin öğretmenlerin birlikte öğrenmesini öne çıkaran bir model olması (Weeks ve Stepanek, 2001) modelin etkililiğinde önemli rol oynamaktadır. Öğretmenler Ders İmecesi sayesinde bilgi ve becerilerini birbirleriyle paylaşarak yeni bilgi ve beceriler kazandıklarını belirtmektedir (Cerbin, 2011). İşbirliğine dayalı bir mesleki gelişim modeli olan Ders İmecesi, takım çalışması ve meslektaş desteği (Serbest, 2014) sayesinde öğretmenlerin mesleki yalnızlıklarının giderilmesine, fikirlerini çekinmeden açıkça belirtmelerine ve mesleki gelişimlerini sahiplenmelerine katkı sağlamaktadır (Lewis ve Hurd, 2011).

Lewis ve Hurd (2011) öğretmenlerin kendi mesleki gelişimlerinin sorumluluğunu üstlenmeleri konusunda modelde yer alan takım çalışmasının etkili olduğunu belirtmektedir. Ders İmecesi Modelinin mesleki gelişime bakış açısında bir paradigma dönüşümünü de beraberinde getirdiğini belirten Lewis ve Hurd (2011), öğretmenleri bir uzmanın kendilerine anlattıklarını dinleyen, not alan ve başkaları tarafından tasarlanmış sınıf içi uygulamaları yaşama geçiren bireyler olarak gören bir mesleki gelişim anlayışı yerine, onları işbirliği içinde araştırarak öğrenen bireyler olarak gören bir mesleki gelişim anlayışının benimsenmesinde Ders İmecesinin önemli payı olduğunu belirtmektedir. Cerbin (2011) ise Ders İmecesi Modelini uygulayan öğretmenlerin bir mesleki gelişim programı kapsamında takım çalışmasını deneyimleme firsatı bulmalarını modelin en önemli özelliği olarak değerlendirdiklerini ve bu sayede birlikte çalışma alışkanlığı kazandıklarını belirtmektedir.

Yoshida (1999) doktora tez çalışması kapsamında beş ay süre ile Japonya'da iki ilkokulda Ders İmecesi uygulamalarını gözlemlemiş ve gözlemleri sonucunda Ders İmecesinin etkili bir mesleki gelişim modeli olduğu kanısına varmıştır. Yoshida (1999) bunun altında yatan en önemli etmenlerden birisinin modelin öğretmenleri işbirliği içinde çalışmaya yönlendirmesi olduğu sonucuna ulaşmıştır. Ayrıca araştırmalar, Ders İmecesi kapsamında öğretmenlerin bir arada çalışmalarının dersin planlanması, çözümlenmesi ve gözden geçirilmesi gibi konularda daha etkili sonuçlar 
doğurduğunu ortaya çıkarmıştır (Hurd ve Licciardo-Musso, 2005). Roback, Chance, Legler ve Moore (2006) üniversitede çalışan yedi öğretmenle gerçekleştirdikleri çalışmalarında Ders İmecesi Modelinin uygulamadaki yansımalarını görmeyi hedeflemiştir. Araştırmanın sonuçları öğretmenlerin işbirliği içerisinde çalışmayı mesleki gelişimleri açısından olumlu değerlendirdiklerini işaret etmiştir. Benzer bir şekilde, Harle (2008) modelin öğretmenler arası işbirliğine katkı sağladığını, Lenski ve Caskey (2009) işbirliği içinde çalışıldığında mesleki gelişim açısından daha etkili sonuçlara ulaşıldığını ve McDonald (2009) ise Ders İmecesini deneyimleyen öğretmenlerin meslektaş dayanışmasını oldukça değerli bulduğunu belirtmiştir.

Araştırma derslerini arkadaşlarıyla dayanışma içerisinde planlayan ve çözümleyen öğretmenler, bu deneyimin mesleki gelişimlerine katkı sağladığını düşünmektedir (Cajkler, Wood, Norton ve Pedder, 2014; Wright, 2009). Ders İmecesi Modelini deneyimleyen öğretmenler model sayesinde işbirliği içinde çalışma becerilerinin gelişim gösterdiğini, bunun da mesleki gelişimlerine katkı sağlayacağını düşündüklerini belirtmektedir (Carroll, 2013; McDowell, 2010).

Türkiye'de yapılan araştırmalar da modelin öğretmen işbirliğinin gelişmesine katkı sağladığını ortaya koymuştur. Örneğin, Erbilgin (2013) öğretmenlerin, Ders İmecesi kapsamında birbirlerine verdikleri geri bildirim ve ortaya çıkan farklı fikirler bağlamında işbirliği içinde çalışmayı faydalı bulduklarını belirtmiştir. Kıncal ve Beypınar (2015) farklı ülkelerde yayımlanan 28 makaleyi inceleyerek Ders İmecesi uygulamasının matematik öğretmenlerinin mesleki gelişimine ve öğrenme sürecinin geliştirilmesine etkisini belirlemeyi amaçlamış ve modelde yer alan öğretmen dayanışmasının öğretmen mesleki gelişimi bağlamında çok önemli rol oynadığını ortaya çıkarmıştır. Gök (2016) İngilizce öğretmenleri ile gerçekleştirdiği çalışmasında Ders İmecesi boyunca işbirliği içerisinde çalışmanın öğretmenler tarafından olumlu değerlendirildiği sonucuna ulaşmıştır.

Öğretmenlerin dayanışma içerisinde çalışarak birbirlerinden yeni bilgiler öğrenmesine olanak tanıması bağlamında önemli bir yere sahip olan Ders İmecesi Modelinin (Günay ve diğ., 2016) öğretmen dayanışmasını destekleyerek öğrencilerin başarılarını olumlu etkileyeceği belirtilmektedir (Kılıç, Demir ve Ünal, 2011). Yukarıda sözü geçen nedenlerden dolayı araştırmacılar, Ders İmecesindekine benzer bir işbirliği barındıran ve sürece yayılan mesleki gelişim modellerinin tercih edilmesini önermektedir (Meissner, 2008).

Öğrenciye ve öğrenme sürecine odaklanma. Ders İmecesi Modeli öğretmenlerin, öğretmen ve öğretme odaklı bakış açısından sıyrılarak, öğrenci ve öğrenme odaklı bakış açısıyla derslerini değerlendirmelerine olanak sağlamaktadır. Araştırma derslerinde öğrencileri özel olarak gözlemleyen öğretmenler, onların derste neler yaptıkları, ne gibi sorular sordukları, hangi konuları anlamakta sıkıntı yaşadıkları vb. noktaları öğrenci gözünden değerlendirme firsatı bulmaktadır. $\mathrm{Bu}$ sayede öğretmenler, derslerde öğretmenin ne yaptığından ziyade öğrencinin ne yaptığını anlama noktasında farkındalık ve gelişim göstermektedir (Lewis, 2000). Weeks ve Stepanek (2001) Ders İmecesinin en ilgi çekici ve heyecan verici 
bölümünün ders gözlemi olduğunu belirtmektedir. Ders gözleminde öğrencilerin düşünme süreçlerini ve tepkilerini gözlemleme firsatı bulan öğretmenler böylelikle öğrencileri daha iyi anlamakta ve derslerini onların gözünden değerlendirme olanăg 1 bulmaktadır (Rhine, 1998; Yoshida, 1999). Bir meslektaşını ders anlatırken gözlemleyen öğretmenler ise bu deneyimin kendileri için çok öğretici olduğunu belirtmekte ve ders gözlemi sayesinde kendilerini öğrencilerin yerine koyabildiklerini ve derse öğrenci gözünden bakabildiklerini belirtmektedir (Cerbin, 2011).

Lewis (2002b) Ders İmecesinin Amerika'daki geleceğini tartıştı̆ı makalesinde uygulamanın, öğrenci tepkilerini dikkate alarak ders planı yapma konusunda öğretmenleri isteklendirdiğini, öğretmenlere ders gözlemleri sayesinde dersin işlenişine öğrenci gözünden bakabilme firsatı sunduğunu ve en önemlisi öğrencilerin derse olan ilgisini artırdığını belirlemiştir. Bu nedenlerle Ders İmecesinin zorluklarına karşın denemeye değer bir mesleki gelişim uygulaması olduğunu belirtmiştir.

Lewis, Takahashi, Murata ve King (2003) Ders İmecesi uygulaması kapsamında toplanan verileri inceledikleri çalışmalarında, bir araştırma dersi kapsamında öğrenci ürünleri, ses kayıtları, gözlem notları, sınıf içi söylem ve konuşmalar gibi farklı türlerde veri toplanabileceğini belirtmiştir. Veri toplama ve çözümleme süreci sayesinde öğretmenlerin zengin bir veri kaynağına ulaşma firsatı buldukları ve bu kaynağın da öğretmenlere dersi öğrenci bakış açısıyla görme olanağı sağladığı belirlenmiştir. Benzer bir şekilde Hurd ve Licciardo-Musso da (2005) on kişiden oluşan bir Ders İmecesi grubu ile yaşadıkları deneyimi aktardıkları makalelerinde, öğretmenlerin Ders İmecesi uygulaması kapsamında öğrencilerinin araştırma derslerinde ürettikleri materyalleri inceleyerek derslerini daha öğrenci odaklı planlayabildiklerini belirlemişlerdir. Model sayesinde öğrencilerin düşünme süreçlerini ders planlama ve öğretim sürecine dahil eden öğretmenler (Harle, 2008), öğrenci odaklı olarak geliştirilen ve uygulanan bu planlar sayesinde öğrencilerinin nasıl öğrendiğini daha iyi anlama firsatı bulmaktadır (Roback ve diğ., 2006).

Ders İmecesi sayesinde öğrencilerin kavramları ezberlemeleri ya da kuralları uygulamalarına değil, derste işlenen konuya verdikleri tepkilere ve nasıl düşündüklerine odaklanma firsatı bulduklarını dile getiren öğretmenler bu durumun uzun süreçte öğrenci başarısını olumlu etkileyeceğini düşündüklerini belirtmektedir (Wright, 2009). Ders İmecesi uygulaması sayesinde öğretmenlerin planlama ve öğretim etkinlikleri sırasında öğrencilerin öğrenmesini göz önünde bulundurdukları gözlemlenmiştir (Lee, 2012). Lenski ve Caskey (2009) üç farklı ortaokulda farklı alanlardan öğretmenlerin katılımıyla gerçekleştirdikleri çalışmalarında öğrencilerin öğrenmesini dikkate alarak ders planı yapılmasında Ders İmecesi Modelinin etkisini incelemiştir. Ders planlama sürecinde öğrencilerinin nasıl öğrendiklerine ve düşünme süreçlerine odaklanmaya yönlendirmesi bakımından modelin öğretmenlerin ders planlama becerisine katkı sağladığı belirlenmiştir.

Carroll (2013) Ders İmecesi sayesinde hizmet öncesi öğretmen eğitiminin önemli bir sorunu olan teori-uygulama arasındaki kopukluğa bir çözüm getirilebileceğini belirtmiştir. Sınıf temelli bir araştırma modeli olan Ders İmecesi 
uygulamasında yer alan danışmanlar, alan uzmanları ve uygulama öğretmenlerinin rehberliğinde çalışan öğretmen adayları, derslerinin başarısını öğrencilerin öğrenmesi odağında değerlendirmeye başlamıştır. Bu bakış açısının ise hem ders planlama hem de uygulama süreçlerinde iyileşmeyi beraberinde getirdiği görülmektedir.

Ders İmecesi Modeli, öğretmenlerin, öğrencilerin düşünme süreçlerini açığa çıkarma ve çözümleme becerilerinin yanı sıra (Lewis, Fischman, Riggs ve Wasserman, 2013) öğrencileri anlama becerilerinin (Kıncal ve Beypınar, 2015) gelişmesine de katkıda bulunan bir modeldir. Özaltun (2014) matematik öğretmenleri ile gerçekleştirdiği çalışmasında Ders İmecesi uygulaması boyunca öğretmenlerin öğrenci düşüncesine ilişkin bilgilerinin nasıl geliştiğini açığa çıkarmayı hedeflemiştir. Ders İmecesi öncesinde, sırasında ve sonunda öğretmenlerin öğrenci düşüncesine ilişkin bilgilerini öğretimlerine nasıl yansıttıkları incelenmiş ve modelin; öğretmenlerin öğrenci düşüncesine ilişkin bilgilerine yönelik farkındalıklarının artmasına, bu bilgileri derslerinde daha etkili ve yoğun bir biçimde kullanmalarına, öğrenci düşüncelerine daha fazla önem vermeye başlamalarına ve öğrencilerinin düşünceleri altında yatan sebepleri sorgulamaya başlamalarına yardımcı olduğu sonucuna ulaşılmıştır. Ders İmecesi süreci sonunda öğretmenler, öğretmenin derste daha geri planda durduğu, öğrencinin ise daha etkin olduğu yöntemleri tercih etmeye başlamaktadır (Bozkurt, 2015).

Öğrenciyi tanıma bakımından süreç içerisinde gelişim gösteren öğretmenlerin (Gözel, 2016; Özbay, 2015) Ders İmecesi sayesinde, öğretme sürecinden ziyade öğrenme sürecine odaklandıkları, öğrencilerle yüz yüze görüşme ve araştırma dersi sonrasında yapılan toplantılar sayesinde ise dersi öğrenci gereksinimleri doğrultusunda tasarladıkları görülmektedir (Gök, 2016).

Alan ve öğretmenlik alan bilgisi. Ders İmecesi Modeli öğretmenlerin alan ve öğretmenlik alan bilgilerinin gelişmesine de yardımcı olmaktadır (Kurt, 2016; Lewis, 2000). Modelin öğrenciyi tanıma, dersin planlanması ve sunumu gibi alanlarda öğretmenlerin öğretmenlik alan bilgisine katkı sağladığı bilinmektedir (Baki, 2012; Fernandez, 2002). Dersin amacına uygun eğitsel materyallerin seçilmesi (Yoshida ve Jackson, 2011), konuya uygun öğretim yöntemlerinin kullanılması, etkili planlama, sınıf yönetimi ve ders tasarımı (Lewis ve Hurd, 2011) gibi konularda da Ders İmecesinin öğretmenlerin mesleki gelişimine katkı sağlayan bir model olduğu görülmektedir (Cerbin ve Kopp, 2006).

Ders İmecesi Modelinde yer alan gözlem ve çözümleme uygulamaları sayesinde sınıf içi uygulamalarını geliştirme olanağı bulan öğretmenlerin (Howell ve Saye, 2016) aynı zamanda alan öğretiminde farklı yöntemler kullanarak risk alma eğilimlerinin arttığı bilinmekte, bu durumun süreç içerisinde öğretmenlerin alan ve öğretmenlik alan bilgilerine katkı sağlayacağı düşünülmektedir (Cajkler ve diğ., 2014).

Lewis ve Tsuchida (1998) Japon öğretmenlerin Ders İmecesi uygulamalarını gözlemledikleri çalışmalarında Ders İmecesinde yer alan araştırma derslerinin sınıf 
içi uygulamaları geliştirdiğini, eğitim programına eklenen yeni konuların ve yöntemlerin etkili bir şekilde yayılmasını sağladığını ve öğretmenlerin sınıf içi davranışları ile ilgili farkındalıklarını artırdığını ortaya çıkarmıştır.

Smith (2008) dört ilkokul öğretmeninden oluşan iki grupla yürüttüğü çalışmasında Ders İmecesinin öğretmenlerin mesleki gelişim gereksinimlerini ne derecede karşıladığını araştırmış ve öğretmenlerin modelin öğretmenlik becerilerine büyük oranda katkı sağladığını düşündüklerini açığa çıkarmıştır. Öğretmenlerin kendi mesleki gelişimlerinin sorumluluğunu alma ve öğretmenliklerini geliştirme anlamında uygulamayı yararlı buldukları belirlenmiştir.

McDonald (2009) Ders İmecesi ilkeleri üzerine kurulu bir mesleki gelişim programını değerlendirdiği çalışmasında öğretmenlerin alan bilgisi, öğretmenlik uygulamaları ve öğrencilerin öğrenme çıktıları arasındaki bağı incelemiştir. Beş öğretmen ve 160 öğrencinin katılımıyla gerçekleştirilen çalışmanın sonuçları, araştırmaya katılan öğretmenlerin alan ve öğretmenlik alan bilgilerinde artış yaşandığını, öğretmenlik uygulamalarının olumlu yönde değişim gösterdiğini ve öğrencilerin çoğunun öğrenme çıtıllarında iyileşme olduğunu ortaya çıkarmıştır.

Wright (2009) Ders İmecesinin matematik alan ve öğretmenlik alan bilgisi ile öğrenci başarısı üzerindeki etkisine yönelik öğretmen görüşlerini araştırmıştır. Araştırmanın bulguları, öğretmenlerin söz konusu üç alanda da Ders İmecesinin kendilerine katkı sağladığını düşündüğünü göstermiştir. Öğretmenler bu uygulama sayesinde yeni problem çözme yöntemleri öğrenerek matematik alan bilgilerini geliştirdiklerini belirtmiştir. Öğretmenler ayrıca hem kendi düzeylerinden hem de diğer düzeylerden öğretmenlerle işbirliği içinde çalışmalarının matematik alan bilgilerine olan özyeterlik inaçlarının artmasına da katkı sağladığını belirtmiştir.

Lewis ve diğ. (2013) üç farklı okulda çalışan matematik öğretmenleriyle yürüttükleri Ders İmecesi çalışmasında çalı̧̧maya katılan öğretmenlerin; matematik alan bilgilerinin ve matematik problemlerinin çözümünde kullandıkları çoklu temsillerin artış gösterdiğini açığa çıkarmıştır. Baki (2012) ise Ders İmecesinin öğretmen adaylarının matematiği öğretme bilgisine katkısını incelediği araştırmasında altısı deney altısı kontrol grubu olmak üzere 12 sınıf öğretmeni adayı ile çalışmıştır. Altı hafta süren Ders İmecesi uygulaması sonunda modelin, öğrenciyi zihinsel olarak etkin tutma, öğrencinin dersle ilgili ön bilgilerini dikkate alma, ders planlama, derste yer alacak etkinliklerin sayısını ve sırasını belirleme konularında öğretmenlere katkı sağladığı sonucuna ulaşılmıştır.

Budak ve diğ. (2011) 24 matematik öğretmen adayı ile geçekleştirdikleri çalışmalarında Ders İmecesinin nasıl uygulandığını ve öğretmen adaylarına neler kazandırdığını incelemiş̧tir. Çalışma sonucunda, öğretmenlerin Ders İmecesi sayesinde matematik öğretim yöntemleri konusunda gelişim gösterdikleri belirlenmiştir. Uygulama sonunda öğretmenler, kavram yanılgıları ve bunları giderme yollarını, yapılandırmacı yaklaşımın sınıfta nasıl uygulanacağını, etkili materyal hazırlamayı ve kullanmayı, grup çalışmasının öğrenciyi nasıl etkilediğini ve buluş 
yoluyla öğrenmenin etkili bir yöntem olduğunu öğrendiklerini belirtmiştir. Ayrıca öğretmenler bu uygulama sayesinde sınıf yönetiminde deneyim kazandıklarını ve sınıf içi uygulamalarıyla ilgili yaratıcılık ve hayal güçlerinin desteklendiğini belirtmiştir.

Aydoğan Yenmez (2012) dört matematik öğretmeni ile gerçekleştirdiği durum çalışmasında Ders İmecesinin öğretmenlerin öğretmenlik alan bilgisine olan katkılarını araştırmış ve modelin öğretmenlerin sınıf yönetimi, öğrencilere yöneltilen sorular ve öğretimin değerlendirilmesi ile ilgili bilgi ve becerilerine katkı sağladığ1 sonucuna ulaşmıştır. Akbaba Dağ (2014) ise araştırmasında sınıf öğretmeni adayları ile çalışmış ve öğretmenlerin kesir öğretim bilgilerinin gelişmesinde Ders İmecesinin katkılarını araştırmıştır. Sekiz hafta süren çalışmanın sonucunda öğretmenlerin kesir bilgisi ve kesir öğretimi bilgilerinin geliştiğini gözlemleyen araştırmacı, Ders İmecesi modelinin alan ve öğretmenlik alan bilgisini geliştirmek için etkili bir mesleki gelişim modeli olduğunu belirtmiştir.

Ders İmecesi uygulamasının matematik öğretmenlerinin mesleki gelişimlerine etkisini inceledikleri araştırmalarının sonucunda Kıncal ve Beypınar (2015), modelin matematik öğretmenlerinin alan bilgisi ve öğretim bilgisine katkida bulunduğu sonucuna ulaşmıştır. Özellikle öğretim stratejileri geliştirme ve materyal tasarımı konusunda modelin öğretmenlerin mesleki gelişimlerine yansımalarının olduğu görülmüştür. Benzer bir şekilde Özbay (2015) ortaokul matematik öğretmenlerinin dönüşüm geometrisinde alan öğretimi bilgilerinin Ders İmecesi sürecinde nasıl geliştiğini incelediği araştırmasında, öğretmenlerin öğrenciyi tanıma ve dersin sunumu konularında gelişim gösterdiklerini belirlemiştir. Öğretmenlerin ayrıca ders planı hazırlama bakımından da süreç içerisinde gelişim gösterdiklerini belirleyen Özbay (2015), farklı matematik konularında öğretmenlerin alan bilgisinin gelişmesi için Ders İmecesinin uygulanmasını önermektedir.

Özen (2015) ortaokul matematik öğretmenlerinin geometrik düşünmelerindeki gelişimi incelediği araştırmasında Ders İmecesi Modelini kullanmıştır. Beş öğretmen ile altı ay süren çalışmasının sonucunda Özen, modelin öğretmenlerin geometrik düşünmelerini geliştirdiği sonucuna varmıştır. Süreç içerisinde öğretmenlerin kullandıkları matematik dilinin, temsillerin ve ders içi öğrenci sorgulamalarının geliştiği gözlemlenmiştir.

Cumhur (2016) Ders İmecesi boyunca matematik öğretmeni adaylarının soru sorma davranışlarındaki gelişimi incelediği çalışmasında öğretmen adaylarının soru sorma davranışlarının akıl yürütme, farklı yaklaşımlar kullanma, sorgulama, öğrenmeyi yönlendirme, öğrencinin yanıtını inceleme, soruları uyarlama ve yanıtı açma boyutlarında gelişim gösterdiği sonucuna ulaşmıştır. Ders İmecesinin soru sorma konusundaki teorik bilgilerin uygulamaya konulması anlamında da öğretmen adaylarının mesleki gelişimlerine katkısı olduğu belirlenmiştir.

Gözel (2016) üçü deney üçü kontrol grubunda yer alan altı sınıf öğretmeni ile gerçekleştirdiği çalışmasında Ders İmecesinin öğretmenlerin problem çözmeye dayalı 
matematiği öğretme bilgilerinin gelişimini incelemiştir. Altı hafta süren çalışma sonucunda Ders İmecesinin; öğrenciyi tanıma, dersin planlanması ve sunumu konularında deney grubunda yer alan öğretmenlerin mesleki gelişimine katkı sağladığı belirlenmiştir. Ayrıca, Ders İmecesi uygulaması sayesinde deney grubu öğretmenlerinin problem çözme adımlarından problemi anlama, çözüm için plan hazırlama, çözüm planını uygulama, çözümü değerlendirme ve problem kurma adımlarında gelişim gösterdikleri sonucuna ulaşılıışıtır.

Yansıtıcı düşünme becerileri. Ders İmecesi Modelinin öğretmenleri yansıtıcı düşünmeye yönlendirdiği de görülmektedir (Lewis ve Tsuchida, 1998). Araştırma derslerini gözlemleyen, video kayıtlarını izleyen ve ders sonrası bir araya gelerek dersle ilgili olumlu ve olumsuz görüşlerini birbirleri ile paylaşan öğretmenler, bu sayede uygulamalarını sorgulayan, eleştiren ve uygulamaları ile ilgili yansıtıcı düşünebilen bireyler olarak gelişim göstermektedir (Lewis, 2000). Araştırma dersini kendi sınıfında uygulayan öğretmenler, meslektaşlarından ders işleyişleriyle ilgili aldıkları geri bildirimleri ve gözlemci olarak katıldıkları derslerde meslektaşlarının uygulamalarından edindikleri fikirleri yansıtıcı bir şekilde değerlendirerek mesleki gelişimlerine katkı sağlamaktadır (Fernandez ve Yoshida, 2004). Derslerde gözlemcilerin topladıkları veriler sayesinde sınıf içi uygulamalarını değerlendirme firsatı bulan öğretmenler, sınıfta neyi, neden ve nasıl yaptıklarını dikkatli bir şekilde düşünme firsatı bulmakta ve bu doğrultuda ders planlarında gerekli değişiklikleri yapabilmek için de yansıtıcı düşünme becerileri sergilemek zorunda kalmaktadır (Cerbin, 2011).

Hurd ve Licciardo-Musso (2005) on kişiden oluşan bir Ders İmecesi grubunun deneyimlerini araştırdıkları çalışmada, öğretmenlerin Ders İmecesi uygulaması kapsamında öğrencilerinin araştırma derslerinde ürettikleri materyalleri inceleyerek derslerine daha yansıtıcı bir gözle bakabildikleri sonucuna ulaşmıştır. McDowell (2010) Ders İmecesinin öğretmen adaylarının Fen Bilgisi dersini işleyişlerini nasıl etkilediğini araştırdığı çalışmasını üç farklı ortaokulda görev yapan altı öğretmen adayı ile yürütmüştür. Araştırmanın sonuçları, Ders İmecesinde yer alan yansıtıcı toplantıların Fen Bilgisi dersinin temel ilkelerinin sinıf uygulamalarına yansitılmasını olumlu yönde etkilediğini, dersin öğrenilmesi ve öğretilmesi konularında öğretmenlere aydınlatıcı bir deneyim sunduğunu ve öğretmenlerin derste yapılması gereken değişikliklerin farkına varmasını sağladığını göstermiştir.

Ders İmecesi Modelini uygulayan öğretmenlerin dersleri ile ilgili daha açık ve dürüst değerlendirmelerde bulundukları da belirlenmiştir (Carroll, 2013). Cajkler, ve diğ. (2014) İngiltere'de bir ortaokulda dört matematik öğretmeni ile gerçekleştirdikleri Ders İmecesi çalışmasında, öğretim yöntem ve tekniklerine karar verilmesi, dersin hedef ve kazanımlarının belirlenmesi ve öğrenci tepkilerinin ve zorlanacakları noktaların tahmin edilmesi konularında öğretmenlerin yansitıcı değerlendirmelerde bulunduklarını ortaya çıkarmıştır.

Ders İmecesi uygulaması kapsamında gerçekleştirilen araştırma derslerinin video ile kaydedilmesinin öğretmenlerin dersle ilgili yansıtıcı bir şekilde düşünmeleri 
için uygun ortam yarattığı görülmektedir (Erbilgin, 2013). Öğretmenler bu sayede dersle ilgili daha ayrıntılı veri toplamakta ve topladıkları veriler doğrultusunda değerlendirmelerine yön vermektedir. Türkiye'de hizmet öncesi öğretmen eğitiminde Ders İmecesi Modelinin uygulanıp uygulanamayacağını tartıştıkları çalışmalarında Günay ve dĭ̆. (2016) Ders İmecesinin gözleme yer vermesi, yansıtıcı tartışmalar içermesi, öğretmenler arası işbirliğini sağlaması, öğretmenlerin birbirlerinden yeni bilgiler öğrenmesine olanak tanıması gibi özellikleri bakımından Okul Deneyimi ve Öğretmenlik Uygulaması dersleriyle bütünleştirerek uygulanabileceğini belirtmiştir.

\section{Tartışma, Sonuç ve Öneriler}

Bu makalede Ders İmecesi Modeli tanıtılmış, dünyada ve Türkiye'de yapılan araştırmalar 1şı̆̆ında modelin öğretmenlerin mesleki gelişimine katkıları incelenmiştir. Ders İmecesi Modelinin araştırmacılar tarafından farklı sayıda aşamadan oluşacak şekilde ele alındığı görülmektedir (Cerbin, 2011; Dudley, 2014; Fernandez ve Yoshida, 2004; Lewis ve Hurd, 2011; Stepanek ve diğ., 2007; Stigler ve Hiebert, 1999). Ancak araştırma dersinin planlanması, uygulanması, çözümlenmesi ve gözden geçirilmesi aşamaları modelin temel aşamalarını oluşturmaktadir.

Öğretmen niteliğinin öğrenci başarısını etkileyen en önemli değişkenlerden birisi olduğu düşünüldüğünde, öğretmenlere sunulan mesleki gelişim olanaklarının niteliğinin ne kadar önemli olduğu daha iyi anlaşılacaktır. Öğrenci başarısını etkileyen en önemli etkenin öğretmen niteliği (Darling-Hammond, 1999; Rice, 2003) ve etkili öğretim (Hattie, 2012) olduğu ve eğitim sisteminin temel hedefinin de öğrenci başarısını artırmak olduğu göz önünde bulundurulduğunda öğretmen niteliğinin önemi de açığa çıkmaktadır. Ya batarsın ya da çıkarsın bakış açısıyla öğretmenlik mesleğine devam etme ya da mesleği bırakma yönünde karar vermesi beklenen ve bir bakıma kaderine terk edilen öğretmenlerin okul yöneticileri ve meslektaşlarından alacakları destekle ve etkili mesleki gelişim uygulamalarıyla öğrenci başarısını artırmada etkili olacağına ilişkin araştırmalara alanyazında sıklıkla rastlanmaktadır (Türk Eğitim Derneği Mem-TEDMEM, 2016). Benzer bir şekilde, Wiliam (2007) da öğrenci başarısının artırılması için öğretmenlerin niteliğinin artırılması gerektiğinin altını çizmekte, bunun ise yaz boyunca sunulan yüz yüze eğitimlerden oluşan geleneksel yöntemlerle yapılamayacağını belirtmektedir. Okullarda öğrencilere daha iyi öğrenme olanakları sunulmak isteniyorsa, öncelikle öğretmenlere hem hizmet öncesinde hem de hizmet içinde daha iyi öğrenme olanakları sunularak işe başlanmalıdır (Feiman-Nemser, 2001). Bu da ancak Ders İmecesi örneğinde olduğu gibi nitelikli ve etkili mesleki gelişim modellerinin işe koşulması ile olanaklıdır.

Ders İmecesi bir mesleki gelişim modeli olarak Japonya' da doğan ve oradan tüm dünyaya yayılan bir modeldir (Fernandez ve Yoshida, 2004). Öğretmenlerin mesleki gelişimlerinin sorumluluğunu alan etkin bireyler olarak yer aldığı modelde bir grup öğretmen bir araya gelerek bir araştırma dersini planlar, uygular, çözümler ve gözden geçirir. Bu dört temel aşamadan geçerek modeli deneyimleyen öğretmenlerin modelin mesleki gelişimlerine olan yansımalarını oldukça olumlu değerlendirdikleri 
görülmektedir. Araştırmalar, Ders İmecesi Modelininin öğretmen işbirliği, öğrenciye ve öğrenme sürecine odaklanma, alan ve öğretmenlik alan bilgisi ve yansitıcı düşünme becerileri gibi konularda öğretmen mesleki gelişimine katkı sağlayan bir model olduğunu göstermektedir.

Ders İmecesi Modelinin aşamaları incelendiğinde, uygulanması emek ve zaman isteyen bir model olduğu göze çarpmaktadır. Öğretmenlerin modeli sahiplenmeleri modelin başarılı olmasında önemli rol oynamaktadır. Bu nedenle modeli uygulama aşamasında öğretmenlerin günlük iş yükleri ve yoğunlukları dikkate alınmalı, gerekiyorsa öğretmenlerin ders programlarında düzenleme ve iyileştirmeler yapılmalıdır. Modelin Türkiye'de doğmadığı ve öğretmenlerin mesleki gelişimlerinde sıklıkla kullanılan bir model olarak kendisine henüz sağlam bir yer bulmadığ düşünüldüğünde, modelin dayandığı temel felsefenin ne olduğu ve nasıl uygulanacağı konusunda öğretmenlere rehberlik edecek kişi ya da kişilere gereksinim duyulacağı açıktır. Bunun yanı sıra öğretmenler modeli uygularken alan öğretimi konusunda destek alabilecekleri kişilere de gereksinim duyabilirler. Modelin etkili bir şekilde yaşama geçirilmesi bu desteğin yeterince sağlanıp sağlanamayacağı ile yakından ilişkili olacaktır.

Gerek hizmet öncesi gerekse de hizmet içi öğretmen eğitiminde Ders İmecesi Modelinden yararlanılarak öğretmenlerin gelişimi desteklenebilir. Model eğitim fakültelerinde öğretmenlik uygulaması dersleri kapsamında denenebilir ve gerekli görülen değişiklikler yapıldıktan sonra uygulanabilir. Modelin hizmet öncesi öğretmen eğitiminde etkili bir şekilde kullanılması için gereksinim duyulan desteklerin yaşama geçirilmesi ile model işlerlik kazanabilir.

Modelin matematik öğretmenlerinin hizmet içi eğitimlerinde sıklıkla kullanıldığ1 görülmektedir (Murata, 2011). Bu deneyimlerden hareketle model eğitimin farklı kademelerinde görev alan farklı öğretmen gruplarıyla da uygulanabilir. Böylelikle modelin Türkiye'de yaygınlaştırılması, iyi giden yönlerinin saptanması ve aksayan yönlerinin düzeltilmesi konusunda ortak bir akıl oluşması sağlanabilir.

Ders İmecesi Modeli okul genelinde uygulamaya geçirilmeden önce gönüllü öğretmenlerle uygulanarak modelin hizmet içi eğitim kapsamında denenip yaygınlaşması sağlanabilir. $\mathrm{Bu}$ deneme uygulaması sonrasında modelde gerekli görülen düzenlemeler ve değişiklikler yapılabilir. Bu aşamada gözlem ve yüz yüze görüşmeler yoluyla modelin uygulanmasında yaşanan aksaklıklar belirlendikten sonra bu aksaklıkların oluşmasını engelleyecek önlemler alınabilir. Modeli deneyimleyen öğretmenler okulda düzenlenecek bir etkinlikte modeli diğer öğretmenlere tanıtabilir, modelle ilgili kendi deneyim ve görüşlerini meslektaşları ile paylaşabilir. Modelin etkili bir şekilde uygulanması için öğretmenlerin desteğe gereksinim duyacakları unutulmamalıdır. Bu nedenle modeli deneyimleyen öğretmenler bir sonraki Ders İmecesi sürecinde diğer öğretmen gruplarına modelin uygulanması konusunda rehberlik edebilir. Modelde yer alan toplantı ve gözlem uygulamalarının gerçekleştirilebilmesi için gerekiyorsa öğretmenlerin ders programlarında değişiklik yapılmalı, okul yönetimi (idare) bu konuda öğretmenlere gereken desteği 
sağlamalıdır. Ders İmecesi süreci sonunda öğretmenlerin edindikleri bilgi ve becerileri diğer meslektaşlarıyla paylaşmaları için firsat sunulmalıdır.

Ders İmecesi Modeli araştırma dersi ile ilgili öğrenci tepkilerini açığa çıkarmayı hedefleyen bir model olduğu için modelle ilgili öğrencilerin de bilgilendirilmesi gerekebilir. Bu bilgilendirme sürecinde öğrenciler, araştırma dersi sonrasında yapılan görüşmelerde dersle ilgili gerçek duygu ve düşüncelerini belirtme konusunda özendirilmelidir.

Bu makalede modelin öğretmenlerin mesleki gelişimine katkı sağladığı noktalar ele alınmıştır. Ancak mesleki gelişim modellerinin etkililiğini belirleyen en önemli etkenlerden birisi de uygulanan modelin öğrenci başarısına olan yansımasıdır. Yapılacak olan çalışmalarda Ders İmecesi Modeli bu yönüyle de ele alınıp, modelin öğrenci başarısına katkısının incelendiği çalışmalar derlenebilir.

\section{Kaynakça}

Akbaba Dağ, S. (2014). Mikroöğretim ders imecesi modeli ile sinıf ögrretmeni adaylarının kesir öğretim bilgilerinin geliştirilmesine yönelik bir uygulama. (Yayımlanmamış doktora tezi, Dumlupınar Üniversitesi, Eğitim Bilimleri Enstitüsü, Kütahya, Türkiye). https://tez.yok.gov.tr/UlusalTezMerkezi/’nden elde edilmiştir. (Tez No. 381235)

Avrupa Ekonomik İşbirliği Örgütü (OECD), (2005). Teachers matter: Attracting, developing and retaining effective teachers. Paris: OECD Publishing.

Aydoğan Yenmez, A. (2012). An investigation of in-service secondary mathematics teachers' evolving knowledge through professional development activities based on modeling perspective (Unpublished doctoral dissertation, Middle East Technical University, Graduate School of Natural and Applied Sciences, Ankara, Turkey). Retrieved from https://tez.yok.gov.tr/UlusalTezMerkezi/'nden elde edilmiştir. (Thesis No. 318810)

Baba, T. (2007). How is lesson study implemented? M. Isoda, M. Stephens, Y. Ohara and T. Miyakawa (Ed.). In Japanese lesson study in mathematics: Its impact, diversity and potential for educational improvement. (pp. 2-7). Singapore: World Scientific Publishing Co. Pte. Ltd.

Baki, A., Erkan, İ. ve Demir, E. (2012, Mayıs). Ders planı etkililiğinin lesson study ile geliştirilmesi: Bir aksiyon araştırması. X. Ulusal Fen Bilimleri ve Matematik Eğitimi Kongresinde sunulan sözlü bildiri, Niğde Ömer Halisdemir Üniveritesi, Niğde. 
Baki, M. (2012). Sınıf ögretmeni adaylarının matematiği öğretme bilgilerinin gelişiminin incelenmesi: Bir ders imecesi (lesson study) çalışması (Yayımlanmamış doktora tezi, Karadeniz Teknik Üniversitesi, Eğitim Bilimleri Enstitüsü, Trabzon, Türkiye). https://tez.yok.gov.tr/UlusalTezMerkezi/'nden elde edilmiştir. (Tez No. 344460)

Ball, D. L., and Cohen, D. K. (1999). Developing practice, developing practitioners: Toward a practice-based theory of professional education. L. Darling-Hammond and G. Sykes (Eds.), In Teaching as the learning profession (pp. 3-31). San Francisco, CA: Jossey-Bass.

Bayram, D. (2010). Türkiye, ABD, Japonya, Ingiltere ve Avustralya'da fen ve fizik öğretmenlerine yönelik mesleki gelişim programlarının karşılaştırılması (Yayımlanmamış doktora tezi, Ankara Üniversitesi, Eğitim Bilimleri Enstitüsü, Ankara, Türkiye). https://tez.yok.gov.tr/UlusalTezMerkezi/'nden elde edilmiştir. (Tez No. 279928)

Bill and Melinda Gates Foundation (2015). Teachers know best. Teachers'views on professional development. Retrieved from http://k12education.gatesfoundation.org/resource/teachers-know-best-teachersviews-on-professional-development/

Birman, B. F., Desimone, L., Porter, A. C., and Garet. M. S. (2000). Designing professional development that works. Educational Leadership, 57(8), 28-33.

Bolam, R. (2000). Emerging policy trends: Some implications for continuing professional development. Journal of In-service Education, 26(2), 267-280.

Boran, E. ve Tarım, K. (2016). The opinions of secondary school mathematics teachers about the lesson study. Turkish Journal of Computer and Mathematics Education (TURCOMAT), 7(1), 259-273.

Borko, H. (2004). Professional development and teacher learning: Mapping the terrain. Educational Researcher, 33(8), 3-15.

Borko, H., Jacobs, J., and Koellner, K. (2010). Contemporary approaches to teacher professional development. International Encyclopedia of Education, 7, 548556.

Bozkurt, E. (2015). Ders araştırması modeli bağlamında ortaokul matematik ögrretmenlerinin ögrretim faaliyetlerine yönelik grup temelli öz-düzenlemelerinin incelenmesi (Yayımlanmamış doktora tezi, Hacettepe Üniversitesi, Eğitim Bilimleri Enstitüsü, Ankara, Türkiye). https://tez.yok.gov.tr/UlusalTezMerkezi/'nden elde edilmiştir. (Tez No. 418199)

Brown Easton, L. (2011). Professional learning communities by design. Putting the learning back into PLCs. USA: Corwin Press. 
Bubb, S., and Earley, P. (2007). Leading and managing continuing professional development. London: Paul Chapman.

Budak, İ., Budak, A., Bozkurt, İ. ve Kaygın, B. (2011). Matematik öğretmen adaylarıyla bir ders araştırması uygulaması. New World Sciences Academy, 6(2), 1606-1617.

Bümen, N. T., Ateş, A., Çakar, E., Ural, G. ve Acar, V. (2012). Türkiye bağlamında öğretmenlerin mesleki gelişimi: Sorunlar ve öneriler. Milli Eğitim, 194, 31-49.

Bütün, M. (2015). Öğretmenlik uygulaması dersinde ders imecesi modelinin uygulama sürecinin değerlendirilmesi: Sorunlar ve çözüm önerileri. Adıyaman Universitesi Ĕgitim Bilimleri Dergisi, 5(2), 136-167.

Cajkler, W., Wood, P., Norton, J., and Pedder, D. (2014). Lesson study as a vehicle for collaborative teacher learning in a secondary school. Professional Development in Education, 40(4), 511-529.

Carroll, C. (2013). Exploring the impact of lesson study on the theory-practice Gap in pre-service teacher education (Unpublished master dissertation, University of Limerick, Limerick, İrlanda). Retrieved from https://core.ac.uk/download/pdf/47243111.pdf

Cerbin, B. (2011). Lesson study. Using classroom inquiry to improve teaching and learning in higher education. Virginia, VA: Stylus Publishing.

Cerbin, W., and Kopp, B. (2006). Lesson study as a model for building pedagogical knowledge and improving teaching. International Journal of Teaching and Learning in Higher Education, 18(3), 250- 257.

Coolahan, J. (2002). Teacher education and the teaching career in an era of lifelong learning. Paris: OECD Publishing.

Cumhur, F. (2016). Matematik öğretmeni adaylarının soru sorma davranışlarının gelişiminin incelenmesi: Bir ders imecesi çalışması (Yayımlanmamış doktora tezi, Karadeniz Teknik Üniversitesi, Eğitim Bilimleri Enstitüsü, Trabzon, Türkiye). https://tez.yok.gov.tr/UlusalTezMerkezi/'nden elde edilmiştir. (Tez No. 448313)

Cumhur, F. ve Güven, B. (2015, Mayıs). Matematik ögretmen adaylarının ögretmenlik uygulaması dersinde kullandıkları soruların öğrencilerin cevabını ilerletme boyutundan incelenmesi. Türk Bilgisayar ve Matematik Eğitimi Sempozyumunda sunulan sözlü bildiri, Adıyaman Üniversitesi, Adıyaman.

Darling-Hammond, L. (1997). Doing what matters most: Investing in quality teaching. New York, NY: National Commission on Teaching and America's Future. Retrieved from https://files.eric.ed.gov/fulltext/ED415183.pdf 
Darling-Hammond, L. (1999). Teacher quality and student achievement: A review of state policy evidence. Seattle, Washington, WA: Center for the Study of Teaching and Policy, University of Washington.

Doig, B., and Groves, S. (2011). Japanese lesson study: Teacher professional development through communities of inquiry. Mathematics Teacher Education and Development, 13(1), 77-93.

Dudley, P. (2014). Lesson study: A handbook. Retrieved from http://lessonstudy.co.uk/wp-content/uploads/2012/03/new-handbookrevisedMay14.pdf

Edmond, G., and Burns. M. (2005). Using technology to train teachers: Appropriate uses of ICT for teacher professional development in developing countries. Washington, WA: World Bank. Retrieved from http://www.infodev.org/en/Publication.13.html

Eraslan, A. (2008). Japanese lesson study: Can it work in Turkey? Eğitim ve Bilim, 33(149), 62-67.

Erbilgin, E. (2013). Sınıf öğretmeni adaylarının ders araştırması hakkındaki görüşleri. Dicle Üniversitesi Ziya Gökalp Eğitim Fakültesi Dergisi, 21, 69-83.

Feiman-Nemser, S. (2001). From preparation to practice: Designing a continuum to strengthen and sustain teaching. Teachers College Record, 103, 1013-1055.

Fernandez, C. (2002). Learning from Japanese approaches to professional development: The case of lesson study. Journal of Teacher Education, 53(5), 393-405.

Fernandez, C., and Yoshida, M. (2004). Lesson study: A Japanese approach to improving mathematics teaching and learning. New Jersey, NJ: Lawrence Erlbaum.

Fraser C., Kennedy A., Reid L., and Mckinney S. (2007). Teachers continuing professional development: Contested concepts, understanding and models. Professional Development in Education, 33(2), 153-169.

Gök, S. Ö. (2016). Lesson study in ELT. TESOL Quarterly, 40(1), 235-257.

Gözel, E. (2016). Ders imecesi çalışmalarıla sınıf öğretmenlerinin problem çözmeye dayalı matematiği öğretme bilgilerinin gelişiminin incelenmesi (Yayımlanmamış doktora tezi, Pamukkale Üniversitesi, Eğitim Bilimleri Enstitüsü, Denizli, Türkiye). https://tez.yok.gov.tr/UlusalTezMerkezi/'nden elde edilmiştir. (Tez No. 445691)

Guskey, T. (2002). Closing the knowledge gap on effective professional development. Educational Horizontal, 87(4), 224-233. 
Günay, R., Yücel Toy, B. ve Bahadır E. (2016). Öğretmen eğitiminde ders araştırması modeli ve Türkiye'de hizmet öncesi öğretmenlik uygulamalarına yönelik bir model önerisi. Uluslararası Sosyal Araştırmalar Dergisi, 9(42), 1224-1237.

Harle, C. B. (2008). The lesson study professional development process: Exploring the learning experiences of elementary and middle school teachers (Unpublished doctoral dissertation). The University of Texas, Austin, USA.

Hattie, J. (2012). Visible learning for teachers. Maximizing impact on learning. London: Routledge.

Howell, J. B., and Saye, J. W. (2016). Using lesson study to develop a shared professional teaching knowledge culture among 4th grade social studies teachers. The Journal of Social Studies Research, 40(2016) 25-37.

Hurd, J. and Licciardo-Musso, L. (2005). Lesson study: Teacher-led professional development in literacy education. Language Arts, 82(5), 388-395.

Joyce, B., and Showers, B. (2002). Student achievement through staff development. Alexandria: Association for Supervision and Curriculum Development.

Kanbolat, O. (2015). Matematik ögretmeni adaylarlyla yürütülen ders imecesinde $d \iota s ̧$ uzmanların paylaşım içerikleri ve rolleri (Yayımlanmamış doktora tezi, Karadeniz Teknik Üniversitesi, Eğitim Bilimleri Ensitüsü, Trabzon, Türkiye). https://tez.yok.gov.tr/UlusalTezMerkezi/'nden elde edilmiştir. (Tez No. 407722)

Kılıç, S., Demir, İ. ve Ünal, H. (2011). Teachers co-learning through mutual collaboration and students' mathematics performance in TIMMS 2007. Procedia Social and Behavioral Sciences, 15(2011), 3258-3262.

Kıncal, R. Y. ve Beypınar, D. (2015). Ders araştırması uygulamasının matematik öğretmenlerinin mesleki gelişimlerine ve öğrenme sürecinin geliştirilmesine etkisi. Mehmet Akif Ersoy Üniversitesi Eğitim Fakültesi Dergisi, 1(33), 186-210.

Kurt, G. (2016). Technological pedagogical content knowledge (TPACK) development of preservice middle school mathematics teachers in statistics teaching: A microteaching lesson study (Unpublished doctoral dissertation, Middle East Technical University, Graduate School of Social Sciences, Ankara, Türkiye). Retrieved from https://tez.yok.gov.tr/UlusalTezMerkezi/. (Thesis No. 439239)

Lee, A. T. (2012). Exploring lesson study as an improvement strategy at a high-stakes accountability school (Unpubolished doctoral dissertation). University of California, Los Angeles, USA).

Lenski, S. J., and Caskey, M. M. (2009). Using the lesson study approach to plan for student learning. Middle School Journal, 40(3), 50-57. 
Lewis, C. (2000, January). Lesson study: The core of Japanese professional development. Papaer presented at the meeting of Special Interest Group on Research in Mathematics Education at American Educational Research Association. New Orleans, Louisiana, LA. Retrieved from http://files.eric.ed.gov/fulltext/ED444972.pdf

Lewis, C. (2002a). A handbook of teacher-led instructional change. Philadelphia, Pennsylvania, PA: Research for Better Schools.

Lewis, C. (2002b). Does lesson study have a future in the United States? Journal of Social Science Education, 3(1), 115-137.

Lewis, C., and Hurd, J. (2011). Lesson study step by step: How teacher learning communities improve instruction. Portsmouth: Heinemann.

Lewis, C., and Tsuchida, I. (1998). A lesson is like a swiftly flowing river: How research lessons improve Japanese education. American Educator, 2(1), 48-56.

Lewis, C., Takahashi, A., Murata, A., and King, E. (2003, April). Developing "the eyes to see students": Data collection during lesson study. Paper presented at the annual meeting of National Council of Teachers of Mathematics, San Antonio, Texas, TX.

Lewis, M. J., Fischman, D., Riggs, I., and Wasserman, K. (2013). Teacher learning in lesson study. The Mathematics Enthusiast, 10(3), 583.

Little, J. W. (2006). Professional community and professional development in the learning-centered school. USA: National Education Association of the United States.

McDonald, S. E. (2009). A model of teacher professional development based on the principles of lesson study (Unpublished doctoral dissertation, Queensland University of Technology, Queensland, Avustralya). https://eprints.qut.edu.au/30389/

McDonough, J., and McDonough, S. (1997). Research methods for English language teachers. London: Arnold.

McDowell, A. (2010). Preservice teachers' use of lesson study in teaching nature of science (Unpublished doctoral dissertation). Georgia State University, Atlanta, Georgia, GA, USA.

Meissner, E. W. (2008). Teacher perception, lesson study and science achievement (Unpublished doctoral dissertation). Seattle Pacific University, Seattle, Washington,WA, USA.

Milli Eğitim Bakanlığı. (2017). 2017-2023 Öğretmen strateji belgesi. Ankara: Öğretmen Yetiştirme ve Geliştirme Genel Müdürlüğü. 
Mokhele, M. (2013). Empowering teachers: An alternative model for professional development in South Africa. Journal of Social Sciences, 34(1), 73-81.

Murata, A. (2011). Introduction: Conceptual overview of lesson study. L. C., Hart, A. Alston and A. Murata (Eds.). In Lesson study research and practice in mathematics education. New York, NY: Springer.

Özaltun, A. (2014). Matematik öğretmenlerinin mesleki gelişimleri: Öğrenci düşüncesi bilgisinin öğretime yansıması (Yayımlanmamış yüksek lisans tezi, Dokuz Eylül Üniversitesi, Eğitim Bilimleri Enstitüsü, İzmir, Türkiye). https://tez.yok.gov.tr/UlusalTezMerkezi/'nden elde edilmiştir. (Tez No. 368253)

Özbay, S. (2015). Ortaokul matematik öğretmenlerinin dönüşüm geometrisinde alan ögretimi bilgilerinin incelenmesi (Yayımlanmamış yüksek lisans tezi, Dokuz Eylül Üniversitesi, Eğitim Bilimleri Enstitüsü, İzmir, Türkiye). https://tez.yok.gov.tr/UlusalTezMerkezi/'nden elde edilmiştir. (Tez No. 395291)

Özen, D. (2015). Ortaokul matematik öğretmenlerinin geometrik düşünmelerinin geliştirilmesi: Bir ders imecesi (Yayımlanmamış doktora tezi, Anadolu Üniversitesi, Eğitim Bilimleri Enstitüsü, Eskişehir, Türkiye). https://tez.yok.gov.tr/UlusalTezMerkezi/'nden elde edilmiştir. (Tez No. 395180)

Rhine, S. (1998). The role of research and teachers' knowledge base in professional development. Educational Researcher, 27(5), 2731.

Rice, J. K. (2003). Teacher quality: Understanding the effectiveness of teacher attributes. Washington, WA: Economic Policy Institute.

Richards, J. C., and Farrell, T. S. C., (2005). Professional development for language teachers: Strategies for teacher learning. United Kingdom: Cambridge University Press.

Riding, P. (2001). Online teacher communities and continuing professional development.Teacher Development, 5(3), 283-295.

Roback, P., Chance, B, Legler, J., and Moore, T. (2006). Applying Japanese lesson study principles to an upper-level undergraduate statistics course. Journal of Statistics Education, 14(2), 1-20. Retrieved from http://ww2.amstat.org/publications/jse/v14n2/roback.html

Serbest, A. (2014). Ders imecesinin etki alanları üzerine bir meta-sentez çallşması (Yayımlanmamış yüksek lisans tezi, Karadeniz Teknik Üniversitesi, Eğitim Bilimleri Enstitüsü, Trabzon, Türkiye). https://tez.yok.gov.tr/UlusalTezMerkezi/’nden elde edilmiştir. (Tez No. 381062) 
Smith, R. R. (2008). Lesson study: Professional development for empowering teachers and improving classroom practice (Unpublished doctoral dissertation). Florida State University, Florida, FL, USA.

Sparks, D. (2002). Designing powerful professional development for teachers and principals. Oxford: National Staff Development Council.

Stepanek, J., Appel, G., Leong, M., Turner Mangan, M., and Mitchell, M. (2007). Leading lesson study: A practical guide for teachers and facilitators. Thousand Oaks, CA: Corwin Press.

Stigler, J. W., and Hiebert, J. (1999). The teaching gap. Best ideas from the world's teachers for improving education in the classroom. New York, NY: Free Press.

Takahashi, A., and Yoshida, M. (2004). Ideas for establishing Lesson-Study communities. Teaching Children Mathematics, 10(9), 436-443.

Türk Eğitim Derneği Mem (2016). 2016 Eğitim değerlendirme raporu. Ankara: Türk Eğitim Derneği.

Uluslararası Öğretme ve Öğrenme Araştırması (TALIS), (2009). Creating effective teaching and learning environments: First results from TALIS. Paris: OECD Publishing.

Wang-Iverson, P., and Yoshida, M. (Ed.). (2005). Building our understanding of lesson study. USA: Research for Better Schools.

Watanabe, T. (2002). Learning from Japanese lesson study. Educational Leadership, 59, 36-39.

Weeks, D.J., and Stepanek, J. (2001). Lesson study: Teachers learning together. Northwest Teacher, 2(2), 2-24.

Wiliam, D. (2007). Changing classroom practice. Educational Leadership, 65(4), 3642.

Wright, T. D. (2009). Investigating teachers' perspectives on the impact of the lesson study process on their mathematical content knowledge, pedagogical knowledge, and the potential for student achievement (Unpublished doctoral dissertation). University of New Orleans, New Orleans, Louisiana, LA USA.

Yıldız, A. (2013). Ders imecesinin matematik ögretmenlerinin problem çözme ortamlarında ögrencilerinin üstbilişlerini harekete geçirmeye yönelik davranışlarına etkisi (Yayımlanmamış doktora tezi, Karadeniz Teknik Üniversitesi, Eğitim Bilimleri Enstitüsü, Trabzon, Türkiye). https://tez.yok.gov.tr/UlusalTezMerkezi/'nden elde edilmiştir. (Tez No. 397296) 
Yoshida, M. (1999). Lesson study: An ethnographic investigation of school-based teacher development in Japan (Unpublished doctoral dissertation). University of Chicago, Illinois, IL, USA.

Yoshida, M., and Jackson, W. C. (2011). Ideas for developing mathematical pedagogical content knowledge through lesson study. L. C., Hart, A. Alston and A. Murata (Eds.). In Lesson study research and practice in mathematics education (pp. 279-288). New York, NY: Springer.

Zepeda, S. J. (2012). Professional development: What works. New York, NY: Routledge. 
A Literature Review on Lesson Study and Its Implications for Teacher Professional Development ${ }^{1}$

\begin{tabular}{|c|c|c|c|}
\hline $\begin{array}{l}\text { ARTICLE TYPE } \\
\text { Review Article }\end{array}$ & $\begin{array}{c}\text { Received Date } \\
10.24 .2018 \\
\end{array}$ & $\begin{array}{c}\text { Accepted Date } \\
05.31 .2019 \\
\end{array}$ & $\begin{array}{c}\text { Published Date } \\
06.08 .2019 \\
\end{array}$ \\
\hline \multicolumn{4}{|c|}{$\begin{array}{c}\text { İlknur Bayram (iD }{ }^{2} \\
\text { TED University }\end{array}$} \\
\hline & $\begin{array}{r}\text { Fatma } \\
\text { Ankar }\end{array}$ & $\begin{array}{l}\text { maz iD } \\
\text { niversity }\end{array}$ & \\
\hline
\end{tabular}

\begin{abstract}
This study aims to discuss the Lesson Study model and its implications for teachers' professional development. This study analyses in detail how Lesson Study, which is regarded as a visionary professional development model, is implemented. Based on the studies conducted on the implementation of Lesson Study both in Turkey and in the world, it was found out that the model contributed to teachers' professional development in important aspects such as fostering teacher collaboration, enabling teachers to be more student and learning focused, improving the content and the pedagogical content knowledge of teachers, and growing teachers as reflective practitioners. It is suggested that the model is implemented by pre-service and in-service teachers teaching at varying levels of education. This will help researchers not only to create a common understanding of how the model should be modified so that it can be better integrated into the Turkish culture but also to determine which aspects of it need to be preserved as they are or modified.
\end{abstract}

Keywords: Lesson study, teacher professional development, visionary professional development.

\footnotetext{
${ }^{1}$ This article has been produced from İlknur Bayram's PhD Thesis "Lesson study: A professional development model led by prep school English instructors" written under the supervision of Prof. Fatma B1kmaz.

${ }^{2}$ Corresponding Author: $\mathrm{PhD}$, Center for Teaching and Learning, Curriculum and Instruction Specialist, Email: ilknur.bayram@tedu.edu.tr, https://orcid.org/0000-0001-8109-8051

${ }^{3}$ Prof. Dr., Faculty of Educational Sciences, Department of Curriculum and Instruction, E-mail: b1kmaz@ankara.edu.tr, https://orcid.org/0000-0002-7156-1425
} 


\section{Purpose and Significance}

In today's world, the fact that it is getting easier to access and share information caused the teaching profession to change substantially. Teachers are no longer regarded as knowledge transmitters, but rather regarded as facilitators of knowledge (MONE, 2017). It is vital that teachers should be equipped with the required knowledge and skills so that they can adapt to the changes in their profession. This will only be possible through in-service training. However, research shows that teachers do not want to take part in professional development activities such as seminars or courses because they are not satisfied with their content and delivery methods (TALIS, 2009).

The quality of professional development opportunities affects the quality of teaching, and the quality of teaching affects student achievement (Sparks, 2002; Darling-Hammond, 1997). With this in mind, it should be emphasized that the quality of education is determined by teacher professional development, which plays a key role in the reforms to be put into action (Bümen, Ateş, Çakar, Ural and Acar, 2012). Teacher professional development has always been a high priority for countries since it facilitates the orientation process of novice teachers (Fraser, Kennedy, Reid and Mckinney, 2007), improves the teaching and learning process (Borko, 2004), and enhances school performance (Bolam, 2000). Therefore, the quality of professional development opportunities offered to teachers should be constantly scrutinized (Mokhele, 2013).

Various models are used for teacher professional development. Although they vary in their contents and methods, they aim to serve a common purpose: to positively affect the in-class performance, attitudes and beliefs of teachers and to increase student achievement (Guskey, 2002). However, the traditional methods of professional development such as one-off seminars are criticized for ignoring the school contexts, in-class practices and current theories of teaching and learning (Borko, Jacobs, and Koellner, 2010) and for their high costs (Ball and Cohen, 1999; Bill and Melinda Gates Foundation, 2015). It is common knowledge that such types of professional development events are not reflected on the in-class practices of teachers and; therefore, they do not have a positive influence on their professional development (Joyce and Showers, 2002).

As opposed to traditional professional development, visionary professional development models increase the pedagogical knowledge of teachers (Borko, 2004) and maximize the quality of teaching (Brown Easton, 2011). In order for a professional development model to be effective, it needs to cater for students' and teachers' needs, to focus on student learning, to support student-centered instruction, and to continue for an extended period of time (Edmond and Burns, 2005). Therefore, teachers should be encouraged to take part in visionary and high-quality professional development models. 
Considered as a visionary professional development model because it is jobembedded, collaborative and research oriented, Lesson Study is widely practiced in Japan and in the other parts of the world (Dudley, 2014). Based on the studies conducted in and outside of Turkey, this study aims to inform the readers about what Lesson Study is and how it is practiced, as well as its implications for teacher professional development.

Lesson study. Lesson Study is a collaborative professional development model (Dudley, 2014) and has been implemented in Japan since 1870s (Fernandez and Yoshida, 2004; Lewis and Tsuchida, 1998; Murata, 2011; Stigler and Hiebert, 1999). It is practiced in Japan to increase the quality of teaching and to provide students with richer learning opportunities (Fernandez and Yoshida, 2004). In this model, teachers collaboratively prepare a lesson plan, teach and observe it, and based on the data they collect through their observations, they modify the lesson plan (Stepanek, Appel, Leong, Turner Mangan, and Mitchell, 2007).

The Japanese term jugyokenkyu, which is a combination of jugyo meaning lesson and kenkyu meaning scientific study, has been translated into English as Lesson Study (Fernandez and Yoshida, 2004; Lewis, 2000; Yoshida, 1999). The Turkish equivalent of the term Lesson Study has taken many forms such as Ders Çalışması (Bayram, 2010), Ders Araştırması (Eraslan, 2008; Erbilgin, 2013; Günay, Yücel Toy, and Bahadır, 2016; İ. Budak, A. Budak, Bozkurt, and Kaygın, 2011; Kıncal and Beypınar; 2015; Özaltun, 2014) and Ders İmecesi (Baki, 2012; Baki, Erkan, and Demir, 2012; Boran, and Tarım, 2016; Bütün, 2015; Cumhur, and Güven, 2015; Kanbolat, 2015; Serbest, 2014; Yıldız, 2013).

Western educators were introduced with the Lesson Study model at the end of the 1990s (Cerbin, 2011) after the publication of the book The Teaching Gap: Best Ideas from the World's Teachers for Improving Education in the Classroom written by Stigler and Hiebert. As a result of this, Lesson Study has begun to spread in America since the start of the 2000s. The model is widely practiced in countries such as Singapore, Hong Kong, China, England, Sweden and Canada (Dudley, 2014).

Steps of the lesson study process. To understand the Lesson Study model well, the steps to be followed to implement it should be clearly defined (Stepanek et all., 2007). Although researchers propose different steps in number, the main steps they advise to go through can be listed under four main headings.

Step 1: Planning the research lesson. The most important task to complete in this step is to plan the first research lesson to be implemented (Yoshida, 1999). Before planning the first research lesson, the group of teachers who will carry out the Lesson Study process comes together. There are some issues to be taken into account before the groups are organized. They should volunteer to try out the model (Dudley, 2014). The number of the group members should not exceed six (Cerbin, 2011). Group members should consider the research lesson as our lesson rather than my lesson (Lewis and Hurd, 2011). Subsequently, they decide on the unit and the topic on which 
they wish to conduct research by taking the long-term and short-term goals of the school into consideration (Lewis and Hurd, 2011). After the lesson aims are defined, teachers work on how to realize these aims during the research lesson.

Step 2: Teaching the research lesson. This step is one of the most important steps in the Lesson Study process because the research lesson is put into action by one of the teachers in the group and the others observe the lesson (Doig and Groves, 2011). The lesson may also be observed by the other teachers in the school or by outside experts (Lewis, 2002a).

Step 3: Analyzing the research lesson. As soon as a research lesson is implemented and observed, teachers get together to analyze it based on their observations and student reactions. During the analysis meetings, teachers share their reflections about the lesson and take notes to modify it as needed (Fernandez and Yoshida, 2004). They, then, prepare the lesson plan for the upcoming research lesson.

Step 4: Sharing the results of the lesson study process. After the Lesson Study process is over, the results should be shared with the other teachers in the school. In Japan, teachers conduct open research lessons and write a report to disseminate the findings (Cerbin, 2011; Dudley, 2014).

Implications of lesson study for teacher professional development. Research conducted on Lesson Study in and outside of Turkey shows that the model contributes to teacher professional development in the aspects listed below.

Teacher collaboration. Teachers state that they improve their teaching skills as a result of the fact that they jointly plan the research lesson, observe and analyze it in teams (Lewis and Tschudia, 1998). Lesson Study emphasizes teachers' learning together (Weeks and Stepanek, 2001) which makes it an effective professional development model. Teachers highlight that they share their knowledge and skills with each other, enabling them to acquire new knowledge and skills (Cerbin, 2011). As a collaborative model, Lesson Study helps teachers fight isolation, openly discuss their ideas, and take ownership of their professional development (Lewis and Hurd, 2011) through teamwork and peer support (Serbest, 2014).

Focusing on students and the learning process. Lesson Study enables teachers to focus on students and their learning process rather than teachers and the teaching process. Teachers closely observe students during a research lesson and thus they have the chance to see what they do in class, what type of questions they ask and what kind of problems they face. This enables teachers to raise awareness about how students actually perform in class (Lewis, 2000). Weeks and Stepanek (2001) assert that the most exciting part of the Lesson Study is lesson observations. Upon observing student reactions and thinking processes, teachers better understand students and look at the lessons from their perspectives. (Rhine, 1998; Yoshida, 1999).

Content and pedagogical content knowledge. Lesson Study helps teachers to improve their content and pedagogical content knowledge (Kurt, 2016; Lewis, 2000). 
The model is known to contribute to the pedagogical content knowledge of teachers in areas such as understanding students, organizing and teaching lessons (Baki, 2012; Fernandez, 2002). Through participating in Lesson Study, teachers get better at choosing educational materials in accordance with lesson aims (Yoshida and Jackson, 2011), using subject-specific teaching methods, effective lesson planning, classroom management, and course design (Lewis and Hurd, 2011).

Reflective thinking. Lesson Study helps teachers to think reflectively. (Lewis and Tschudia, 1998). Through observing and analyzing research lessons, teachers grow as professionals who question and criticize their classroom practices (Lewis, 2000). When teachers implement a research lesson in their own classes, they have the opportunity to reflect on their performance based on the feedback they get from their colleagues (Fernandez and Yoshida, 2004). They also assess their in-class practices by using the data gathered through observations and by critically examining what they do and why they do it in class. Teachers implementing Lesson Study have to possess reflective thinking skills to be able to modify their lessons in an effective way (Cerbin, 2011).

\section{Discussion and Conclusions}

The literature review has shown that although the steps in Lesson Study's implementation might vary from one researcher to the other, the model is comprised of four main steps; planning, implementing, analyzing and revising a research lesson (Cerbin, 2011; Dudley, 2014; Fernandez and Yoshida, 2004; Lewis and Hurd, 2011; Stepanek et all., 2007; Stigler and Hiebert, 1999).

The findings of the studies have further shown that Lesson Study contributes to teacher professional development in important aspects such as fostering teacher collaboration, enabling teachers to be more student and learning focused, improving the content and the pedagogical content knowledge of teachers, and growing teachers as reflective practitioners.

Lesson Study is a labor and time-intensive model. Therefore, teachers engaged in it should be supported and guided throughout the process. This guidance might be offered to them by knowledgeable others who have expertise in the implementation of the model and the teaching of a specific subject matter.

Professional development of pre and in-service teachers might be supported through Lesson Study. The model might be piloted and tried out in the faculties, which train teachers, so that the quality and the efficiency of it could be improved before it is practiced with a larger group of teachers. The model might also be used by different groups of pre and in-service teachers teaching at varying levels of education. 